\title{
İlçeler Düzeyinde Sosyal Sermaye Analizi: Konya ve Karaman Örneği'
}

Ali ERBASSI, Department of Management and Organization, Vocational School of Social Sciences, Selcuk University, Turkey; e-mail: aerbasi@selcuk.edu.tr

\section{The Analysis of Social Capital in Districts Level: The Case of Konya and Karaman $^{2}$}

\begin{abstract}
The purpose of this research is to propose a model for can be analyzed social capital structure in districts level and in this context, is to analyze social capital structure of two cities' central and their districts (Konya and Karaman) that located TR52 Level 2 Region. To achieve this goal, social capital index were calculated in 37 districts that in Konya (31) and in Karaman (6), social capital map was edited and it is examined that relationship between social capital level and social and economic development level. It is expected to be the results of this study should guide to public administrators to determining the strategy and planning activities about strengthen the social capital whom the districts have a low index and should contribute to research about social capital that desired doing at districts level.

Keywords Social Capital, District Level, Development, Konya, Karaman.

JEL Classification Codes $\quad$ : O O150, O470, R110

\section{$\ddot{\mathbf{O z}}$}

$\mathrm{Bu}$ araştırmanın amacı, ilçeler düzeyinde sosyal sermaye yapısının analiz edilebilmesine yönelik bir model önermek ve TR52 Düzey 2 bölgesinde yer alan iki ilin (Konya ve Karaman) merkez ilçeleri ve bağlı ilçelerinin sosyal sermaye yapısını bu bağlamda analiz etmektir. Bu amaca ulaşabilmek için, Konya'da (31) ve Karaman'da (6) bulunan 37 ilçenin sosyal sermaye endeksleri hesaplanmış, sosyal sermaye haritası düzenlenmiş ve bölgenin sosyal sermaye düzeyi ile sosyal ve ekonomik gelişmişlik düzeyi arasındaki ilişki incelenmiştir. Araştırmanın, düşük endekse sahip ilçelerin sosyal sermayelerinin güçlendirilmesine yönelik strateji belirleme ve planlama çalışmalarında amme yöneticilerine ve ilçeler düzeyinde yapılmak istenen sosyal sermaye araştırmalarına katkı sağlaması beklenmektedir.
\end{abstract}

Anahtar Sözcükler $\quad$ : Sosyal Sermaye, İlçe Düzeyi, Gelişme, Konya, Karaman.

1 Bu makale "Konya ve Karaman'in Merkez ve Bağlı İlçelerinin Sosyal Sermaye Yapısının Analizi" adlı ve 14401012 nolu Selçuk Üniversitesi Bilimsel Araştırma Projeleri (BAP) Koordinatörlüğ̈̈ tarafindan desteklenen proje kapsamında elde edilen veriler kullanılarak üretilmiştir. Yazar, verdiği destekten ötürü Selçuk Üniversitesi $B A P$ Koordinatörlüğ̈̈'ne teşekkürlerini sunar.

2 The present study was conducted using the data obtained within the context of the project titled "The Analysis of Social Capital Structure in Konya and Karaman Centre and Their Districts" and numbered 14401012 and supported by the Selcuk University Scientific Research Projects (BAP) Coordination Unit. The author thanks to Selcuk University Scientific Research Projects (BAP) Coordination Unit for the support. 


\section{Giriş}

Rekabet gücünün ve ekonomik kalkınmanın, fiziki sermaye unsurlarının gelişimiyle mümkün olduğunu öne süren üretime yönelik bakış açısı, son yıllarda önemli bir dönüşüme uğramaktadır. Gerek işletmeler gerekse diğer örgütler bu bakış açısının eksik yönüne odaklanmakta ve fiziksel sermaye unsurlarından daha önemli olduğuna inandıkları bir kavramla meşgul olmaktadırlar: Bu kavram "sosyal sermaye" kavramıdır. Literatürde sosyal sermayenin ölçümüne yönelik çeşitli yöntemler ortaya atılmıştır. Bu yöntemler, sosyal sermaye yapılarının analizine de konu olmuştur. Bu araştırmalarda bölgesel rekabet gücünün artırılması ve ekonomik kalkınmanın sağlanabilmesi, bölgelerin sosyal sermaye unsurlarının da diğer ekonomik, teknolojik vb. unsurlarla birlikte güçlenmesiyle mümkün olabileceği rapor edilmektedir. Bölgelerin sosyal sermaye yapılarını ortaya koymaları, yapacakları planlama faaliyetlerine yön verecek olup kaynakların etkin kullanımına imkân taniyabilecektir.

Günümüzde örgütlerin, bölgelerin ve ülkelerin fiziksel ve finansal sermayeleri, sürdürülebilir rekabet üstünlüğü elde etmek açısından tek başına yeterli görülmemektedir. Bölgesel rekabet gücünün artırılabilmesi ve kalkınmanın geliştirilebilmesi, bölgenin sahip olduğu sosyal sermayeyi verimli değerlendirebilmesi ile doğru orantılıdır. Çünkü yerel bir ilçenin bile bölgesel düzeyde, bir bölgenin ülkesel düzeyde rakipleri bulunmaktadır. Aynı coğrafyada bulunmasa ve hatta aynı sektörde faaliyet göstermese bile başka bir coğrafya, bir bölgenin rakibi olmaktadır. Bu bağlamda, sosyal sermayenin etkin bir şekilde değerlendirilmesi tüm çevreler açısından gerekliliktir. Bu gereklilik, literatürde yapılan araştırmalar incelendiğinde, ilçeler düzeyinde ilgi konusu olmamıştır. Oysaki ilçeler düzeyinde sosyal sermaye düzeylerinin incelenmesi, ilçelerin bölgesel kalkınma açısından fiziksel ve finansal sermaye unsurları dışında hangi unsurlara öncelik vermeleri gerektiğini ve böylece kaynakların hangi alanlarda öncelikle kullanılması gerektiği konusunda yöneticilere fikir verebilecektir.

Türkiye örnekleminde sosyal sermaye konusunda yapılmış araştırmalar incelendiğinde, sosyal sermaye ölçümünü ilçeler düzeyine indirgeyen hiçbir çalışmaya rastlanmamıştır. Çalışmamız, TR52 Düzey 2 Bölgesi olan Konya ve Karaman bölgesinde ilçeler düzeyinde sosyal sermaye analizi yapmayı amaçlamaktadır. Bu amaca yönelik olarak iki ile bağlı 37 ilçenin sosyal sermaye endeks değerleri hesaplanmış, ilçelerin sosyal sermaye haritaları düzenlenmiş ve bu örneklemde sosyal sermaye ile sosyal ve ekonomik gelişmişlik arasındaki ilişki incelenmiştir. 


\section{Sosyal Sermaye Ölçümü ve Göstergeleri}

Sosyal sermayeyi ölçmenin tek bir yöntemi bulunmamaktadır. Ancak literatürde yapılan araştırmalar incelendiğinde sosyal sermayeyi ölçebilmek için iki ana yöntemin kullanıldığı görülmektedir. Bu yöntemler, gözlem yöntemi ve anket yöntemidir. Gözlem yönteminde; ilgili toplum/örgüt/takım içindeki suçların oranı, senet kullanma oranı, ticari işletmelerin ne ölçüde anonimleştiği, kamudaki bürokratik işlemler, yolsuzluklar, boşanma oranları gibi unsurlar esas alınarak sosyal sermayenin belirlenmesi yoluna gidilmektedir (OECD, 2001: 43). Anket yönteminde ise, bireylerin sosyal sermaye düzeylerinin toplamının, o toplumun sosyal sermaye düzeyini ifade ettiği varsayımından hareketle, bireylerin sosyal sermaye düzeyleri ölçülmeye çalışılır. Sosyal sermayenin ölçümüne yönelik anket yönteminin uygulanmasında, dünyada en sık kullanılan araştırma Dünya Değerler Araştırmaları'nın yapmış olduğu "Dünya Değerler Anketi (WVS-World Values Survey)"dir. Güven bileşeni içerisinde bu ankete ilişkin bilgilere yer verilmiştir.

Bir grubun sosyal sermayesi ölçülüyor veya sosyal sermaye kavramı bireylerden ziyade grupların sahip olduğu bir unsur olarak ele alınıyorsa, veri setleri üzerinden değerlendirmeler yapılarak ölçüm gerçekleştirilebilir. Grubun güven düzeyini ölçmek içinse anket yöntemine başvurulabilir. Dolayısıyla gözlem ve anket yöntemlerinin analiz çalışmalarında eş zamanlı olarak kullanımı mümkündür. Grubun sosyal sermaye düzeyinin, bireylerin sosyal sermayelerinin toplamından oluştuğunu kabul eden bakış açısına göre ise, sosyal sermaye ile ilgili faktörler esas alınarak bireylerin sosyal sermaye düzeyleri ölçülür ve bireylerin sosyal sermaye düzeylerinin toplamı, o grubun sosyal sermaye düzeyi olarak kabul edilir.

Sosyal sermayenin ölçümünde kullanılan göstergeler, literatürde farklı şekillerde sınıflandırılmıştır. Yerli ve yabancı literatürde yapılan kapsamlı araştırmalar sonucunda belirlenen sosyal sermaye göstergelerinin bir kısmına çeşitli kısıtlar nedeniyle burada değinilmeyecektir. Bu konudaki kısıtlar şöyledir:

- $\quad$ Literatürde sosyal sermayenin ölçümüne yönelik kullanılan göstergelerden bazıları, ülke ölçeğinde yapılan hesaplamalarda kullanılan göstergelerdir. Bu göstergelerin yerel ölçeklerde hesaplanabilmesi için gerekli olan verilerin temini oldukça zordur ve hatta bir kısmı mümkün görünmemektedir. Örneğin basın özgürlüğü, insan hakları, politik haklar, mahkemelerin bağımsızlığı, mülkiyet haklarının korunması, sivil ve politik şiddetin görünme oranı, politik istikrarsızlık, demokrasi oranı, rüşvet oranı gibi. Bu göstergelere çalışmamızda yer verilmemiştir.

- Bazı çalışmalarda sosyal sermayenin ölçümünde kullanılan bazı göstergelerin, sosyal sermaye dışındaki sermaye türlerini ölçmeye yönelik göstergeler olduğunu düşünmekteyiz. Örneğin yüksek nitelikli nüfusun oranı, 100 bin kişi başına doktor 
sayısı, 100 bin kişi başına sinema sayısı, kız okullaşma oranı, yükseköğrenim oranı, iş başvuru oranı, okuma yazma oranı gibi. Bu nitelikteki göstergelerin büyük kısmı beşeri sermayeyi ölçmeye yönelik göstergelerdir. Bu nedenle literatürde sosyal sermaye göstergesi olarak kullanılmış olsalar bile bu göstergelere çalışmamızda yer verilmemiştir.

- Bazı çalışmalarda kullanılmış olan bazı göstergeler, bireysel düzeyde sosyal sermaye ölçümünde kullanılabilecek göstergelerdir. Örneğin komşuluk-mahalle ilişkileri, aile-arkadaşlık ilişkileri, belirsizliğe tolerans düzeyi gibi. $\mathrm{Bu}$ gibi göstergeler de çalışmamızda kapsam dışı bırakılmıştır.

Burada literatürde kullanılmış olan tüm sosyal sermaye göstergelerinin açıklamalarına yer vermek yerine, araştırmamızın konusuyla sınırlandırabilmek için ilçe ölçeğinde kullanılabilecek sosyal sermaye göstergelerinin açıklamalarına yer verilmiştir. Bu kısıtlar dikkate alındığında, sosyal sermayeyi ilçe düzeyinde ölçebileceğini düşündüğümüz 18 sosyal sermaye göstergesinin burada kısaca açıklamalarına yer verilmiştir.

Bin Kişi Başına Düşen Yeni Girişimci Sayısı: Bin kişi başına yeni girişimci sayıları arttıkça sosyal sermaye endeks değerinin yükselmesi beklenmektedir. Blassio ve Nuzzo (2009) çalışmasında bu göstergeyi “Girişimcilik Oranı” olarak kullanmıştır.

Kadın İstihdam Oranı: Kadın istihdam oranı arttıkça sosyal sermaye endeks değerinin yükselmesi beklenmektedir. Blassio ve Nuzzo (2009) çalışmasında bu göstergeyi kullanmıştır.

Vergi Tahsilat/Tahakkuk Oranı: Vergi tahsilat/tahakkuk oranı arttıkça sosyal sermaye endeks değerinin yükselmesi beklenmektedir. Tüysüz (2011) çalışmasında bu göstergeyi kullanmıştır. Putnam (1995b) tarafından "Vergi yükümlülüklerini yerine getirme oranı" adıyla kullanılmıştır.

Onbin Kişi Başına Düşen Sinema Sayısı: Onbin kişi başına düşen sinema sayısı arttıkça sosyal sermaye endeks değerinin yükselmesi beklenmektedir. Filiztekin (2009) çalışmasında bu göstergeyi “100 bin kişi başına sinema sayısı” olarak kullanmıştır.

Bin Kişi Başına Düşen Günlük Yerel Gazete Tirajı: İlçelerdeki bin kişi Başına Düşen Günlük Yerel Gazete Tirajı arttıkça sosyal sermaye endeks değerinin yükselmesi beklenmektedir. Tüysüz (2011) ve Filiztekin (2009) çalışmalarında bu göstergeyi kullanmışlardır. 
Bin Kişi Başına Düşen Aylık Yerel Dergi Tirajı: İlçelerdeki bin kişi başına düşen aylık yerel dergi tirajı arttıkça sosyal sermaye endeks değerinin yükselmesi beklenmektedir. Tüysüz (2011) çalışmasında bu göstergeyi kullanmıştır.

Elektrik Kayı/Kaçak Oranı: Elektrik kayıp/kaçak oranı arttıkça sosyal sermaye endeks değerinin düşmesi beklenmektedir. Tüysüz (2011) çalışmasında bu göstergeyi kullanmıştır.

Intihar Oranı: İntihar oranı arttıkça sosyal sermaye endeks değerinin düşmesi beklenmektedir. Tüysüz (2011), Bullen ve Onyx (1998) çalışmalarında bu göstergeyi kullanmışlardır.

Suç Oranı: Suç oranı arttıkça sosyal sermaye endeks değerinin düşmesi beklenmektedir. Paldam ve Svendsen (2000), Grootaert (1998), Putnam (1995b) çalışmalarında bu göstergeyi kullanmışlardır.

Merkezi Yönetimde Kadın Temsil Oranı: Merkezi yönetimde kadın temsil oranı arttıkça sosyal sermaye endeks değerinin yükselmesi beklenmektedir. Dünya Bankası (2002) tarafından "Yetkilendirme, temsil yetkisi oranları" olarak kullanılmıştır.

Yerel Yönetimlerde Kadın Temsil Oranı: Yerel yönetimlerde kadın temsil oranı arttıkça sosyal sermaye endeks değerinin yükselmesi beklenmektedir. Bullen ve Onyx (1998) çalışmalarında bu göstergeyi kullanmışlardır.

Güven Oranı: Güven oranı arttıkça sosyal sermaye endeks değerinin yükselmesi beklenmektedir. Fukuyama (2001), Grootaert (1998) ve Dünya Değerler Araştırması'nda sosyal sermayenin karşılığı olarak kullanılmıştır. Helliwell ve Putnam (1995) tarafından "Yerel yönetimlerden memnuniyet göstergeleri" olarak kullanılmıştır.

Kaba Boşanma Hızı: Kaba boşanma hızı arttıkça sosyal sermaye endeks değerinin yükselmesi beklenmektedir. Tüysüz (2011) çalışmasında bu göstergeyi kullanmıştır.

Bin Kişi Başına Düşen Dernek Sayısı: Bin kişi başına düşen dernek sayısı arttıkça sosyal sermaye endeks değerinin yükselmesi beklenmektedir. Uğuz ve arkadaşları (2011a), Tüysüz (2011), Kara (2008), Grootaert (1998), Putnam (1995b) tarafından kullanmıştır.

Bin Kişi Başına Düşen Vakıf Sayısı: Bin kişi başına düşen vakıf sayısı arttıkça sosyal sermaye endeks değerinin yükselmesi beklenmektedir. Uğuz ve arkadaşları (2011a), Tüysüz (2011), Grootaert (1998), Putnam (1995b) tarafından derneklerle aynı anlamda 
kullanmıştır. Ayrıca Kara (2008) tarafından çalışmamızdaki gibi ayrı bir gösterge olarak değerlendirilmiştir.

Net Göç Hızı: Net göç hızı, göç edebilecek her bin kişi için net göç sayısıdır. Göç, bir toplumda, üyeler arasındaki güven ve kişiler arası ilişkilerin gücünü etkileyerek sosyal sermaye düzeyini azaltır (Rupasingha, 2006: 91). Dolayısıyla net göç hızı arttıkça sosyal sermaye endeks değerinin düşmesi beklenmektedir. Rupasingha vd. (2006), Schiff (1992), Glaeser vd. (2000), Tüysüz (2011) ve Filiztekin (2009) çalışmalarında kullanmışlardır.

Yerel Seçimlere Katılım Oranı: Yerel seçimlere katılım oranı arttıkça sosyal sermaye endeks değerinin yükselmesi beklenmektedir. Fukuyama (2001) ve Tüysüz (2011) çalışmalarında bu göstergeyi kullanmışlardır.

Genel Seçimlere Katılım Oranı: Genel seçimlere katılım oranı arttıkça sosyal sermaye endeks değerinin yükselmesi beklenmektedir. Uğuz ve arkadaşları (2011a) ile Putnam (1995b) tarafindan kullanılmıştır.

\section{Literatür Özeti}

Literatürde sosyal sermayeyi konu edinen ampirik çalışmalar incelendiğinde, sosyal sermayenin ekonomik sonuçlarına odaklanan çalışmaların önemli bir yer kapladığı, bu çalışmaların ise genellikle sosyal sermaye ile ekonomik büyüme/gelişim ilişkisine vurgu yaptığı görülmektedir (Örneğin; Koç ve Ata, 2012; Şavkar, 2011; Boulila, 2008; Woodhouse, 2006; Sabatini, 2005; Annen, 2003; Zak ve Knack, 2001; Temple ve Johnson, 1998; Knack ve Keefer, 1996; Helliwell ve Putnam, 1995; Putnam, 1993; Mankiw vd., 1992). Sosyal sermayeye yönelik yapılan deneysel çalışmalar, sosyal sermaye artışını ekonomik kalkınma, eğitim düzeyi, suç oranı, politikaların başarıyla uygulanması gibi konularda önemli bir faktör olarak saptanmıştır (Çalışkan, 2010: 2). Ayrıca sosyal sermayenin tespitine yönelik ekonometrik modeller geliştiren çalışmalar da bulunmaktadır (Örneğin Perez vd., 2006; Rupasingha vd., 2006).

Literatürde sosyal sermaye ile ilgili yapılmış deneysel çalışmaları, örgütlerde yapılan ve toplum düzeyinde yapılan çalışmalar olarak ikiye ayırabiliriz. Konumuzla daha yakından ilgisi olduğu için araştırmamızın literatür özetinde toplum düzeyinde yapılan çalışmalara yer verilmiş, örgütler düzeyinde yapılan araştırmaları burada zikretmekten kaçınılmıştır.

Sosyal sermaye unsuruna yönelik toplumsal düzeyde yapılan önemli çalışmalardan birisinde Putnam (1993), sosyal sermaye ile ilgili İtalya deneyimini ve ekonomik gelişim ile ilişkisini ele almakta, ayrıca bu konuda ABD’deki eksik yönlere 
odaklanmaktadır. Yazar ABD’nin bazı bölgelerinde yetersiz eğitim ve sağlıksız yaşam koşullarının sosyal sermaye ile ilişkili olduğunu, ülkede sosyal sermayeyle ilgili derin eksiklikler olduğuna vurgu yapmaktadır.

Putnam (1995a) bir başka çalışmasında, ABD'deki sosyal sermaye yapısının özellikle son 20-30 yıldır zayıfladığına vurgu yapmaktadır. Yazar bu çalışmasında, ABD’de sosyal sermaye ve sivil toplum kavramlarının demokrasi ve demokratikleşme üzerindeki etkileri incelenmiştir. Çalışmada İtalya ve Çin örnekleri üzerinde de durulmaktadır. Putnam'a göre; işsizliğin ve suç oranlarının azalmasında, hükümetlerin daha etkin çalışmasında ve yolsuzlukların azalmasında sosyal sermaye son derece etkilidir. $\mathrm{Bu}$ bağlamda, sosyal sermayenin ekonomik büyümeye de olumlu katkı sağladığını ifade etmiştir. Amerika'nın gündemini meşgul etmesi gereken sorunun sivil toplum örgütlerinin sosyal bağlılık, sivil katılım ve sivil güven için nasıl farklı eğilimlerin ortak bir amaç etrafında toplanabileceği olması gerektiğini savunmaktadır.

Sabatini (2005) araştırmasında, İtalya'da ekonomik kalkınmanın kalitesinin, sosyal sermaye ile olan çeşitli bağlantılarını değerlendirmektedir. Çalışmada kalkınma kalitesi; insan gelişimi ve kentsel ekosistemlerdeki sağlık kurumları, kamu hizmetleri, sosyal koruma, toplumsal cinsiyet eşitliği, işgücü piyasalarının göstergeleri ile ölçülmüştür. Sosyal sermaye ise; güçlü aile bağları, zayıf gayri resmi bağlar, gönüllü organizasyonlar ve siyasi katılım olmak üzere dört ana faktörle ölçülmeye çalışılmıştır. Sosyal sermayenin ve insan gelişiminin farklı boyutları arasındaki nedensel ilişki daha sonra yapısal denklemler ile modellenmiştir. Bu çalışma, Putnam'ın (1995b) sivil toplum örgütlerinin sosyal bağ oluşturmadaki olumlu rolü ile ilgili iddialarına kanıt niteliğindedir. Araştırmanın sonunda, güçlü aile bağlarıyla şekillendirilmiş sosyal sermayenin, ekonomik kalkınmanın üzerinde pozitif bir etkisi olmadığı, aksine, zayıf aile bağlarının sonucunda sivil toplum örgütlerinde bir araya gelen farklı bireylerin bilgi paylaşımı ve güven duygusuyla ekonomik kalkınmanın tetiklenebileceği savunulmaktadır.

Rupasingha ve diğerleri (2006) araştırmalarında, bütün Birleşik Devletler eyaletlerinde, sosyal sermayenin ortaya çıkışında katkısı bulunan faktörleri araştırmışlardır. $\mathrm{Bu}$ araştırmada, sosyal sermayenin teorik olarak önemli faktörleri olarak kabul edilen; etnik köken, gelir dağılımı eşitsizliği, eğitim, yaş, toplumsal bağlılık ve kadın işgücünün üretime katkısı gibi bireysel ve toplumsal bir takım veriler kullanılmıştır. Bulgulara göre; sosyal sermaye endeksi, eğitim düzeyinde $(0,740)$ en yüksek standart beta katsayısına sahiptir. Bunu yaş ve toplumsal bağlılık (uzun süredir aynı eyalette ikamet edenler) takip etmektedir. Kadın işgücünün üretime katılımı, nüfusun yaş ortalaması ve toplum bağlılık yüksek elastikiyete sahiptir. Düşük elastikiyet ise etnik köken durumunda ortaya çıkmaktadır. Bu araştırma, Coleman (1990), Putnam (1993), Putnam (1995a), Alesina ve La Ferrara (2000) ve Glaeser ve diğerlerinin (2002) yaptığı araştırmaları tamamlar niteliktedir. Araştırmanın 
sonucunda yüksek endeksli sosyal sermaye üretimine sahip toplumların ekonomik ve sosyal problemlerle daha etkin mücadele ettiği savunulmaktadır.

Perez ve diğerleri (2006) araştırmalarında, sosyal sermayenin ekonomik büyüme üzerindeki etkisini teorik ve ampirik modellerle ölçmüşlerdir. Teorik modellerinde, sosyal sermayeyi oluşturan faktörlerden "gelir artışı, sosyal sermayedeki yıpranma oranı, işbirliği maliyeti ve güven ağlarının genişliği” kullanılmıştır. Ampirik modelde sosyal sermayenin ölçümü 1965-2001 yılları arasında 23 OECD ülkesi için yapılmıştır. Sonuçlara göre, söz konusu yıllar arasında OECD ülkelerinde, sosyal sermaye düzeyinde genel bir artış görülmektedir. $\mathrm{Bu}$ artışlar ekonomik büyüme düzeyinde pozitif bir etkiye yol açmıştır. ABD'de durgunluk dönemlerinde sosyal sermayenin düşmesi ile ilgili hipoteze rağmen güven duygusunun hala var olduğu gözlemlenmiştir. Diğer taraftan, Danimarka, İsviçre, Belçika, İngiltere ya da İspanya gibi diğer ekonomilerde genişleme ve daralma dönemlerinde, sosyal sermayenin daha düzensiz bir evrim gösterdiği tespit edilmiştir.

Carpenter ve diğerleri (2004), yaptıkları araştırmada, Güneydoğu Asya'da Bangkok ve Ho Chi Minh City’de sosyal sermaye ve çevresel yönetimin karşılaştırmalı bir analizini gerçekleştirmişlerdir. Araştırmanın amacı sosyal sermayenin niteliğinin belirlenmesidir. Bu bağlamda, özellikle güven ve işbirliğini etkileyen cinsiyet faktörü ayrıntılı olarak incelenmiştir. Anket ve doğrudan gözlem yöntemleri kullanılan araştırma sonucunda, her iki kentin düşük gelirli yerleşim yerlerinde de çevresel iyileştirmelere yönelik genel eylemlere katılım oranının yüksek olduğu ve daha önemlisi katılımcıların verilen süre ve mekân çerçevesinde ortak hedeflere bağlı kaldıkları vurgulanmıştır.

Sosyal sermayenin toplum düzeyinde tespitiyle ilgili Türkiye'de yapılan çalışma sayısı oldukça sınırlıdır. Bu sınırlı sayıdaki çalışmalardan birisinde Şavkar (2011) yüksek lisans tezinde sosyal sermaye unsurlarının ekonomik kalkınma üzerindeki etkilerini inceleyen ampirik bir çalışma yapmıştır.

Tüysüz (2011) tarafından hazırlanmış uzmanlık tezinde, Türkiye'de bölgelerin sosyal sermaye düzeyleri hesaplanmış ve genel kalkınmışlık seviyeleri ile ilişkisi araştırılmıştır. Bu kapsamda, Türkiye'deki Düzey 2 bölgelerine ait belirlenen değişkenlere Temel Bileşenler Yöntemi uygulanmış ve 26 Düzey 2 bölgesini kapsayan sosyal sermaye endeksi değerlerini elde etmiştir. Bölgelerin sosyal sermaye endeks değerleri bölgelerin Gayri Safi Katma Değer ve Sosyo-Ekonomik Gelişmişlik Endeksi sonuçlarına göre karşılaştırılmalı olarak analiz etmiş ve sonuçları yorumlamıştır. Analiz sonucunda iki temel eğilim gözlemlenmiştir. İlk olarak bölgelerin genel gelişmişlik düzeyleri ile sosyal sermaye düzeyleri arasında yüksek bir ilişki olduğu tespit edilmiştir. İkinci olarak ise bazı gelişmiş bölgelerin ekonomik gelişme düzeyine kıyasla sosyal sermaye düzeyinin düşük kaldığı belirlenmiştir. Çalışmada bu tespitlerden hareketle, yeni bölgesel gelişme politikalarında 
bölgelerin fiziki sermayeleri kadar sosyal sermayelerinin de göz önünde bulundurulması gerektiği vurgulanmıştır.

Uğuz ve arkadaşları (2011a) yürüttükleri TÜBİTAK projesinde Türkiye'nin sosyal sermaye stoğunu ve toplumun sosyal sermaye profilini belirlemeye yönelik bir alan araştırması yapmışlardır. Buna yönelik olarak Türkiye genelini temsil etmek üzere Uğuz ve arkadaşları (2011a, 2011b) TÜİK İstatistiki Bölge Birimleri Sınıflandırması'na göre 12 farklı bölgedeki 19 farklı ilden 1577 kişiye anket uygulayarak Türkiye'deki toplumun sosyal sermaye düzeyini belirlemeye çalışmışlardır. Bu araştırmada sosyal sermaye unsuru; güven, katılım, sosyal adanmışlık, özyeterlilik, sosyal girişkenlik ve hayırseverlik düzeyi esas alınarak tespit edilmiştir. Araştırmada gerçekleştirilen saha araştırması sayesinde, Türk toplumunun ağ kurma davranışları (bireylerin iş, eğitim veya meslek hayatlarında başarılı olmaları ve işlerini yapmaları için gerekli olan kişilerle ilişki kurmak ve sürdürmek için sergiledikleri davranışlar) belirlenmiş, bireylerin ağ alanına (bireysel bir ağda yer alan kişilerin yaş, cinsiyet, statü düzeyi, meslek grubu gibi hususlarda farkl1laşma derecesi) ilişkin bilgiler derlenmiş, toplumun ağ yapısının farklılaşma derecesi (birey ve iletişimde olduğu kişiler arasındaki benzer veya farklı özellikler) belirlenmiş ve bireylerin ağ yoğunluğu (ağdaki bireylerin birbirleriyle arasındaki sıkı ve yakın ilişkiler) ölçülmüştür. Böylece farklı demografik özelliklere sahip (yaş, cinsiyet, etnik yapı, yaşanılan yer, kentkır, meslek grubu, statü vb.) bireylerin ağ özellikleri ortaya konulmuştur. Araştırmanın sonucunda Türk insanının başkalarına olan güven düzeyinin düşük $(\% 14,5)$ olduğu, ancak bireylerin her ne kadar diğer insanların genelde kendi sorunları ile ilgilendiklerini düşünseler dahi, yine de herhangi bir sorun karşısında toplumun bir araya gelebilme kapasitesine yönelik bir inanca sahip olduğu vurgusu yapılmaktadır. Başka bir deyişle Türk insanında yardımlaşma ve dayanışma eylemleri, herhangi bir sorunun yaşanması ile birlikte duygusal bir tepki olarak ortaya çıkmakta, ne var ki duygu yoğunluğunun azalmasılyla birlikte bu eylemler de rasyonel ve kalıcı bir yapıya kavuşamadan sona ermektedir. Ayrıca araştırmada Türkiye'de sivil toplum kuruluşlarına üyelik oranlarının son derece düşük olduğu, Türkiye genelinde sivil toplum kuruluşlarına vatandaş katılımının dar ve çeşitli sosyal grupların göreceli olarak temsil edilebildiği bir şekilde gerçekleştiği belirtilmiştir. Bunun yanı sıra güven konusunda insanların kendilerini emniyette hissetme düzeyleri analiz edilmiş ve Türkiye'de bireylerin, büyük ölçüde kendilerini emniyette hissettikleri sonucuna ulaşılmıştır. Ağbağların yapısal analizi sonuçlarına göre Türkiye insanın ağ alanının dar, ağ yoğunluğunun yüksek ve bunla bağlantılı olarak ağdaki farklılaşma düzeyinin düşük olduğu belirtilmiştir. Son olarak araştırmada akrabalıklar ve aile üyeliği gibi göreceli olarak homojen gruplar arasındaki ilişkilerde ortaya çıkan bağlayıcı sosyal sermaye düzeyinin yüksek olduğu, bunun ise farklı insanları bir araya getiren/homojen olmayan sosyal ağlardan türeyen köprü kuran sosyal sermaye düzeyinin Türkiye'de düşük olduğu sonucuna ulaşılmıştır. Araştırmada Türkiye için asıl olanın, herhangi bir grubun veya topluluğun işleyişsini daha verimli hale getiren ve kayganlaştırıcı bir madde olarak işlev gören güveni 
yaratabilmek ve yaratılan güveni grup üyeliğinin ötesine taşıyabilmek olduğu vurgusu yapılmıştır.

Filiztekin (2009) çalışmasında, Türkiye'de bölgelerin farklı boyutlardaki göreli başarısını özetleyebilecek, 50 değişkeni içeren ve iki aşamalı temel bileşenler analizi kullandığı genel bir rekabet endeksi geliştirmiştir. Alt bileşenler olarak ekonomik canlılık ve etkinlik endeksi, emek piyasası endeksi, yaratıcılık endeksi, insan sermayesi endeksi, fiziki altyapı endeksi ve sosyal sermaye endeksi olmak üzere altı endeks hesaplaması yapmıştır. Yazar çalışmasında sosyal sermaye endeksi için hane halkı büyüklüğü, 100 bin kişi başına doktor sayısı, 100 bin kişi başına sinema sayısı, bin kişi başına gazete tirajı, kız okullaşma oranı, bin kişi başına STK sayısı, kişi başına konut elektrik tüketimi, net göç oranı ve okuma yazma oranı olmak üzere dokuz değişken kullanmıştır. Araştırmanın sonucunda Türkiye illeri arasında sosyal sermaye düzeyi en yüksek iller sırasıyla Ankara, İstanbul, Muğla, İzmir ve Yalova iken, en düşük sosyal sermaye düzeyine sahip iller sırasıyla Muş, Ağrı, Mardin, Bitlis ve Şırnak olarak tespit edilmiştir.

Kara (2008) çalışmasında Türkiye illerinin ve bölgelerinin görece olarak rekabet edebilirliklerini değerlendirebilecek, 30 değişkeni içeren ve temel bileşenler analizi kullandığ 1 rekabet endeksi geliştirmiştir. Alt bileşenler olarak iktisadi yap1, yenilikçilik kapasitesi, altyapı ve erişilebilirlik, beşeri sermaye ve sosyal sermaye olmak üzere beş alt başlıkta değerlendirme yapmıştır. Yazar çalışmasında sosyal sermaye endeksi için on bin kişiye düşen vakıf sayısı ve dernek sayısı olmak üzere iki değişken kullanmıştır. Araştırmanın sonucunda bölgesel rekabet edebilirlik düzeyi en yüksek bölgeler sırasıyla TR10 (İstanbul), TR51 (Ankara) ve TR31 (İzmir) iken; en düşük bölgeler sırasıyla TRB2 (Van, Muş, Bitlis, Hakkâri), TRA2 (Ağrı, Kars, Iğdır, Ardahan) ve TRC3 (Mardin, Batman, Şırnak, Siirt) olarak tespit edilmiştir. Türkiye'nin batı ve kuzey kesimlerindeki bölgelerin yüksek düzeyde sosyal sermayeye sahip olduğu; Doğu ve Güneydoğu Anadolu bölgelerinde sosyal sermaye seviyesinin düşük olduğu sonucuna ulaşılmıştır.

Konya ve Karaman illerinin ilçeler düzeyinde sosyal sermaye yapısını incelediğimiz bu çalışmada, yukarıda aktarılmış araştırmalardaki bulgular da dikkate alınarak, ilçelerin sosyal sermaye endeks değerleriyle SEGE (Sosyal ve Ekonomik Gelişmişlik Endeksi) değerleri arasındaki ilişki sorgulanmıştır. Bu doğrultuda şu hipotez oluşturulmuştur: Hipotez 1. Konya ve Karaman illerinin ilçeler düzeyinde sosyal sermaye endeks değerleriyle SEGE (Sosyal ve Ekonomik Gelişmişlik Endeksi) değerleri arasında anlamlı bir ilişki var mıdır? 


\section{Uygulama}

\subsection{Araştırmanın Amacı ve Önemi}

$\mathrm{Bu}$ araştırmanın amacı, ilçe düzeyinde sosyal sermaye yapısının analiz edilebilmesine yönelik bir model önermek ve bu amaçla Türkiye İstatistiki Bölge Birimi sınıflandırmasına göre TR52 Düzey 2 bölgesinde yer alan iki ilin (Konya ve Karaman) merkez ilçeleri ve bağlı ilçelerinin sosyal sermaye yapısını analiz etmektir.

Sosyal sermayeyle ilgili yapılmış araştırmalar incelendiğinde, bu çalışmaların aile, komşuluk, şehir ve toplum düzeylerinde yapıldığını söyleyebiliriz (Briggs, 1997: 112). $\mathrm{Bu}$ çalışmaların bir adım daha ileriye götürülerek ilçeler düzeyinde yapılması, bu araştırmanın özgün yönünü oluşturmaktadır. Türkiye örnekleminde sosyal sermaye konusunda yapılmış araştırmalar incelendiğinde, sosyal sermaye ölçümünü ilçeler düzeyine indirgeyen hiçbir çalışmaya rastlanmamıştır.

Sosyal sermaye, yatay ağlar ve karşılıklılık temelli yerel katılımı sağlayarak ve problemli alanlarda bile ekonomik gelişmişliğe ve demokratikleşme yoğunluğuna pozitif katkı sağlayarak bölgesel yeni politikaların geliştirilmesinde önemli bir rol oynar (Mayer, 2003: 108). Konya ve Karaman'ın ilçeleri düzeyinde sosyal sermaye analizinin yapılması, bölgeye yönelik sonraki yıllara ilişkin stratejilerin tespitinde ve kaynakların etkin kullanımına yapacağı katkı anlamında son derece büyük öneme sahiptir. Araştırmanın, düşük endekse sahip ilçelerin sosyal sermayelerinin güçlendirilmesine yönelik strateji belirleme ve planlama çalışmalarında amme yöneticilerine ve ilçeler düzeyinde yapılmak istenen sosyal sermaye araştırmacılarına yön gösterici olması beklenmektedir.

\subsection{Araştırmanın Metodolojisi}

Çok değişkenli istatistiksel analizlerde, $\mathrm{n}$ tane bireye (nesne) ilişkin $\mathrm{p}$ tane değişken (özellik) incelenmektedir. Bu özelliklerden birçoğunun birbiriyle ilişkili ve p'nin oldukça büyük olması durumunda, analiz sonuçlarının yorumlanması ve özetlenmesi çok güç olmaktadır. Bu gibi durumlarda Temel Bileşenler Analizi (Principal Component Analysis), Kümeleme Analizi (Cluster Analysisi), Ayırma Analizi (Discriminant Analysis), Kanonik Korelasyon Analizi (Canonical Correlation Analysis), Faktör Analizi (Factor Analysis), Çok Değişkenli Varyans Analizi (Multivariate Analysis of Variance) gibi yöntemlere başvurulmaktadır. Değişkenler arasında bir bağımlılığın bulunması ve dolayısı ile bağımsız olmamaları durumunda istatistiksel analiz sonuçlarının yorumu oldukça güç olmaktadır. Bu gibi durumlarda başarılı sonuçlar veren tekniklerin başında Temel Bileşenler Analizi gelmektedir (Sangün, 2007: 17). Temel bileşenler analizinde, $\mathrm{n}$ birey (gözlem) ve $\mathrm{p}$ 
değişkenden oluşan veri matrisi, x’in p boyutlu uzaydaki durumu olarak düşünüldüğünde, her birey bir noktayı göstermek üzere, veri matrisi çok sayıda noktadan oluşan bir topluluk olarak ifade edilebilir. $\mathrm{Bu}$ matriste eğer ham veri kullanılıyor ise varyans-kovaryans matrisinden, standartlaştırılmış veri kullanılıyor ise korelasyon matrisinden yararlanılmaktadır. Oldukça farklı sonuçlar verebilen bu iki yoldan hangisinin seçileceği konusunda en önemli belirleyici, verilerin ölçü birimleridir. Eğer değişkenlerin ölçü birimleri aynı ise varyans-kovaryans matrisinden, değilse korelasyon matrisinden yararlanılması önerilir (Özdamar, 2004: 502).

Temel bileşenler analizi tekniğinin temel özellikleri, çok sayıdaki özelliklerin belli bir nitelik yönünden özetlenmesine ve ortak nitelikler üzerinden soyutlama yapılabilmesine imkân vermesi, çok sayıda ve farklı boyuttaki bilgi setinin kapsadığı temel ve ortak anlamı veya bilgi özünü açığa çıkarabilmeyi sağlaması, değişkenler arası bağımlılık yapısını gidermesi ve diğer geleneksel endeks tekniklerinin aksine değişkenlere uygulamacının isteğine bağlı olabilecek ağırlıklar verilmesini engelleyerek objektifliği artırmasıdır (Kara, 2008: 185). Bu nedenlerden dolayı çalışmamızda, ilçelerin sosyal sermaye düzeylerinin tek bir bileşik endeks şeklinde tespit edilebilmesi için temel bileşenler analizi kullanılmıştır. Temel Bileşenler Analizi yöntemini uygulamak için SPSS 18.0 (Statistical Package for the Social Sciences) bilgisayar programından faydalanılmıştır.

\subsection{Araştırmanın Evreni ve Örneklemi}

Araştırmaya Konya iline bağlı 31 ilçe ve Karaman iline bağlı 6 ilçe dâhil edilmiştir. Dolayısıyla TR52 Düzey 2 bölgesi olan Konya ve Karaman illerine bağlı 37 ilçenin tümü araştırmaya dâhil edildiğinden evren ve örneklem ayrımına gidilmemiştir.

\subsection{Veri Toplama Aracının Geliştirilmesi}

Araştırmada kullanılmak üzere toplanan değişken sayısı 18'dir. Bu değişkenler: Bin Kişi Başına Düşen Yeni Girişimci Sayısı, Kadın İstihdam Oranı, Vergi Tahsilat/Tahakkuk Oranı, Onbin Kişi Başına Düşen Sinema Sayısı, Bin Kişi Başına Düşen Günlük Yerel Gazete Tirajı, Bin Kişi Başına Düşen Aylık Yerel Dergi Tirajı, Elektrik Kayıp/Kaçak Oranı, İntihar Oranı, Suç Oranı, Merkezi Yönetimde Kadın Temsil Oranı, Yerel Yönetimlerde Kadın Temsil Oranı, Güven Oranı, Kaba Boşanma Hızı, Bin Kişi Başına Düşen Dernek Sayısı, Bin Kişi Başına Düşen Vakıf Sayısı, Net Göç Hızı, Yerel Seçimlere Katılım Oranı ve Genel Seçimlere Katılım Oranı'dır. Veriler temin edilmiş olmasına rağmen, değişkenler arası korelasyon analizi incelemesi ve Kaiser Myer Olkin (KMO) testi sonuçları dikkate alınarak 6 değişken (Bin Kişi Başına Düşen Yeni Girişimci Sayısı, Kadın İstihdam Oranı, Onbin Kişi Başına Düşen Sinema Sayısı, Bin Kişi Başına Düşen Aylık Yerel 
Dergi Tirajı, Güven Oranı ve Genel Seçimlere Katılım Oranı) analiz dışına çıkarılmıştır. Dolayısıyla araştırmanın analiz kısmında kullanılan değişken sayısı 12'dir.

İlçelerin sosyal sermaye endeks değerleri hesaplamasına geçilmeden önce, doğru değişkenlerin analize tabi tutulduğunun tespiti, araştırma sonuçlarının geçerliliği açısından kritik önem taşımaktadır. Bu nedenle tüm değişkenler, Kaiser-Meyer-Olkin (KMO) testi, Bartlett küresellik testi ve korelasyon analizine tabi tutulmuştur.

Kaiser-Meyer-Olkin (KMO) testi, örneklem yeterliliği ölçüsüdür. KMO testi, kısmi korelasyon katsayılarının büyüklükleri ile gözlenen korelasyon katsayıları büyüklüklerini karşılaştırmak için kullanılan bir tekniktir. KMO testi sonucu ulaşılan değer, veri kümesinin analize uygunluk derecesini ölçmektedir. KMO testi değerlerinin $1,00 \leq \mathrm{KMO} \leq 0,90$ aralığında olması verilerin "mükemmel" derecede, $0,90 \leq \mathrm{KMO} \leq 0,80$ aralığında olması "iyi” derecede, $0,80 \leq \mathrm{KMO} \leq 0,70$ aralığında olması "orta" düzeyde, 0,70 $\leq \mathrm{KMO} \leq 0,60$ aralığında olması "zayıf ama kabul edilebilir" düzeyde olduğunu göstermektedir. Değerin 0,6'dan küçük olması veri setinin uygun olmadığını göstermektedir (Tüysüz, 2011: 101-2). Kimi kaynaklarda (Örneğin Field, 2000) bu orana ait alt sınırın 0,50 olarak alınması gerektiği belirtilmektedir.

Konya ve Karaman'a bağlı 37 ilçenin sosyal sermaye endekslerine ulaşmak için yerli ve yabancı yazında sosyal sermaye alanında kullanılan göstergeler esas alınarak oluşturulan veri setinin temel bileşenler analizine uygun olabilmesi için KMO testinin yanı sıra, "korelasyon matrisi birim matrise eşittir" şeklinde ifade edilen sıfır (yokluk) hipotezinin "korelasyon matrisi birim matrise eşit değildir" alternatif hipotezine karşı sınanması ve sıfır hipotezinin reddedilmesi gerekmektedir. Bu ise küresellik adı verilen Barlett testi ile kontrol edilir. Bartlett (1950) tarafından verilerin küreselliğini açıklamak için kullanılan bu test, sonraki bazı çalışmalarda değişkenlerin tutarlılığını açıklamak için kullanılmıştır.

H0: R=I (Korelasyon matrisi ile birim matris arasında fark yoktur. Değişkenler arasındaki ilişkiler önemsizdir.)

$\mathrm{H1}$ : $\mathrm{R} \neq \mathrm{I}$ (Korelasyon matrisi ile birim matris arasında fark vardır. Değişkenler arasındaki ilişkiler önemlidir.)

Tablo: 1'de, araştırmamızda kullanılan sosyal sermaye göstergeleri esas alınmak suretiyle hesaplanan Kaiser-Meyer-Olkin ve Bartlett testlerinin sonuçları gösterilmiştir. 
Tablo: 1

Kaiser-Meyer-Olkin (KMO) ve Bartlett Testleri Sonuçları

\begin{tabular}{|l|l|r|}
\hline \multicolumn{2}{|c|}{ Kaiser-Meyer-Olkin Örneklem Yeterliliği Testi } &, 610 \\
\hline \multirow{3}{*}{ Bartlett Küresellik Testi } & Ki-kare & 101,848 \\
& Serbestlik Derecesi & 66 \\
& P &, 003 \\
\hline
\end{tabular}

Sosyal sermaye endeksinin ilçeler düzeyinde hesaplanabilmesi için oluşturduğumuz veri setinin uygunluğu için öncelikle KMO testi yapılmıştır. Yukarıda aktarıldığı üzere değişkenlerin tutarlı kabul edilebilmesi için KMO değerinin kimi kaynaklarda 0,60 kimi kaynaklarda ise 0,50'den yüksek olması gerekmektedir. 18 değişken esas alınarak yapılan KMO testi sonucu elde edilen değer 0,426 çıkmıştır. Bu oran, değişkenlerin tutarlılığı açısından yeterli olmadığ için bazı değişkenler değerlendirme dışı bırakılarak yeniden hesaplamalar yapılmıştır. 0,60 ve 0,50 değerinin uygunluğu konusunda istatistik kaynaklarındaki tartışmalara girmeksizin KMO testi sonucunda 0,60 değerine ulaşılıncaya kadar analizler yeniden yapılmış ve sonuçta 6 değişken analiz dışına çıkarıldığında istenen değere ulaşılmıştır. Dolayısıyla 6 değişken analiz kapsamı dışında bırakılmış ve kalan 12 değişken üzerinden yapılan KMO testi sonucunda elde edilen değer 0,610 olmuştur. $\mathrm{Bu}$ sonuç, eşleştirilen değişkenlerin korelasyonlarının diğer değişkenler tarafından zayıf ancak kabul edilebilir düzeyde açıklandığını, örneklem büyüklüğünün yeterli olduğunu ve veri setinin temel bileşenler analizine uygun olduğunu göstermektedir. Bartlett testi sonucunda elde edilen p olasılık değeri anlamlılık derecesi $0,003(0,05$ 'den küçük) olduğu için sıfir hipotezi reddedilmiştir. Buna göre veriler normal dağılıma sahiptir ve değişkenler arasında ilişki vardır (değişkenler uygundur).

$\mathrm{Bu}$ kapsamda analizlerde kullanılan değişkenler şunlardır: Vergi Tahsilat/Tahakkuk Oranı, Bin Kişi Başına Düşen Günlük Yerel Gazete Tirajı, Elektrik Kayıp/Kaçak Oranı, İntihar Oranı, Suç Oranı, Merkezi Yönetimde Kadın Temsil Oranı, Yerel Yönetimlerde Kadın Temsil Oranı, Kaba Boşanma Hızı, Bin Kişi Başına Düşen Dernek Sayısı, Bin Kişi Başına Düşen Vakıf Sayısı, Net Göç Hızı ve Yerel Seçimlere Katılım Oranı. Verileri temin edilmiş olmasına rağmen analize dâhil edilmeyen 6 değişken: Bin Kişi Başına Düşen Yeni Girişimci Sayısı, Kadın İstihdam Oranı, Onbin Kişi Başına Düşen Sinema Sayısı, Bin Kişi Başına Düşen Aylık Yerel Dergi Tirajı, Güven Oranı ve Genel Seçimlere Katılım Oranı'dır.

Maddelerin ortak bir faktördeki varyansı birlikte açıklama oranları Tablo: 2'de verilmiştir. Tablodaki katsayıların incelenmesinden, en yüksek açıklanan varyansa sahip üç değişkenin sırasıyla Bin Kişi Başına Düşen Günlük Yerel Gazete Tirajı, Genel Seçimlere Katılım Oranı, Vergi Tahsilat / Tahakkuk Oranı olduğu görülmektedir. Varyans açıklama 
oranlarında 0,10 'dan küçük bir değer yer almadığı için sorunlu bir değişsen olmadığ kanısına varılmıştır.

Tablo: 2

\section{Açıklanan Varyans}

\begin{tabular}{|l|c|}
\hline \multicolumn{1}{|c|}{ Gösterge } & Açıklanan Varyans \\
\hline Vergi Tahsilat / Tahakkuk Oranı &, 798 \\
\hline Bin Kişi Başına Düşen Günlük Yerel Gazete Tirajı &, 808 \\
\hline Elektrik Kayıp / Kaçak Oranı &, 621 \\
\hline İntihar Oranı &, 730 \\
\hline Suç Oranı &, 561 \\
\hline Merkezi Yönetimde Kadın Temsil Oranı &, 517 \\
\hline Yerel Yönetimlerde Kadın Temsil Oranı &, 766 \\
\hline Kaba Boşanma Hızı &, 749 \\
\hline Bin Kişi Başına Düşen Dernek Sayısı &, 756 \\
\hline Bin Kişi Başına Düşen Vakıf Sayısı &, 678 \\
\hline Net Göç Hızı &, 765 \\
\hline Genel Seçimlere Katılım Oranı &, 802 \\
\hline
\end{tabular}

Araştırmada kullanılan değişkenler arasındaki ilişkiyi görebilmek için korelasyon matrisi incelenmiş ve Tablo: 3'te gösterilmiştir. Bu aşamada KMO ve Bartlett testleri sonucunda analiz kapsamı dışına çıkarılan 6 değişken ilişkiye dâhil edilmemiş, geri kalan 12 değişken arasındaki ilişki incelenmiştir.

Tablo: 3

Değişkenler arası Korelasyon Matrisi

\begin{tabular}{|l|l|l|l|l|l|l|l|l|l|l|l|l|}
\hline & VTTO & GGT & EKKO & İO & SO & MYKTO & YYKTO & KBH & DS & VS & NGH & YSKO \\
\hline VTTO & 1 & & & & & & & & & & & \\
\hline GGT &,- 161 & 1 & & & & & & & & & & \\
\hline EKKO &, 215 &, 024 & 1 & & & & & & & & & \\
\hline İO &, 016 &,- 058 &,- 004 & 1 & & & & & & & & \\
\hline SO &,- 098 &, $495^{* *}$ &, 092 &, 183 & 1 & & & & & & & \\
\hline MYKTO &,- 192 &, 151 &,- 013 &, 160 &,- 033 & 1 & & & & & & \\
\hline YYKTO &,- 167 &, $710^{* *}$ &, 014 &, 028 &, $417^{*}$ &, 244 & 1 & & & & & \\
\hline KBH &, 038 &, 324 &,- 195 &,- 003 &, 065 &, 120 &, $356^{*}$ & 1 & & & & \\
\hline DS &,- 078 &, 131 &, 116 &, 014 &, 004 &, 121 &, 172 &,- 056 & 1 & & & \\
\hline VS &, 110 &,$- 335^{*}$ &, 019 &,- 214 &,- 177 &,- 183 &,- 249 &,- 188 &, 242 & 1 & & \\
\hline NGH &, 169 &, $485^{* *}$ &, $371^{*}$ &,- 083 &, $463^{* *}$ &, 040 &, $414^{*}$ &, 080 &, 056 &, 033 & 1 & \\
\hline YSKO &,- 074 &,- 079 &, 247 &,- 068 &, 113 &,- 105 &,- 221 &,$- 513^{* *}$ &,,- 161 &,- 090 &, 190 & 1 \\
\hline
\end{tabular}

**. Correlation is significant at the 0.01 level (2-tailed).

*. Correlation is significant at the 0.05 level (2-tailed). 


\section{Tablo: 4}

\section{Sosyal Sermaye Göstergeleri, Notasyonları, Hesaplama Yöntemi ve Veri Kaynağı}

\begin{tabular}{|c|c|c|c|c|c|}
\hline Nu. & Gösterge & Notasyonu & Hesaplama Yöntemi & Veri Kaynağı & $\begin{array}{c}\text { Analizlerde } \\
\text { Kullanılma } \\
\text { Durumu }\end{array}$ \\
\hline 1 & $\begin{array}{l}\text { Bin Kişi Başına Düşen } \\
\text { Yeni Girişimci Sayısı }\end{array}$ & GS & $\begin{array}{l}\text { (Yılsonu işletme sayısı - Yılbaşı işletme sayısı) / } \\
\text { İlçe nüfusu) } \times 1.000\end{array}$ & $\begin{array}{l}\text { - SGK Konya Sosyal } \\
\text { Güvenlik İl Müdürlüğü } \\
\text { - SGK Karaman Sosyal } \\
\text { Güvenlik İl Müdürlüğü } \\
\text { - TÜİK }\end{array}$ & Kullanılmadi \\
\hline 2 & Kadın İstihdam Oranı & KİO & $\begin{array}{l}\text { Yılsonu tüm işletmelerdeki toplam kadın çalışan } \\
\text { sayısı / Yılsonu tüm işletmelerdeki toplam çalışan } \\
\text { sayısı }\end{array}$ & $\begin{array}{l}\text { - SGK Konya Sosyal } \\
\text { Güvenlik İl Müdürlüğü } \\
\text { - SGK Karaman Sosyal } \\
\text { Güvenlik İl Müdürlüğ̈ü }\end{array}$ & Kullanılmadi \\
\hline 3 & $\begin{array}{l}\text { Vergi Tahsilat / } \\
\text { Tahakkuk Oranı }\end{array}$ & VTTO & $\begin{array}{l}2013 \text { y1lı vergi tahsilat toplamı (TL) / } 2013 \text { yilı } \\
\text { vergi tahakkuk toplamı (TL) }\end{array}$ & $\begin{array}{l}\text { - Konya Vergi Dairesi } \\
\text { Başkanlığı } \\
\text { - İlçe Vergi Dairesi } \\
\text { - İlçe Malmüdürlüğü }\end{array}$ & Kullanıldı \\
\hline 4 & $\begin{array}{l}\text { Onbin Kişi Başına Düşen } \\
\text { Sinema Sayısı }\end{array}$ & SS & $\begin{array}{l}\text { (İlçedeki toplam sinema sayısı / İlçe nüfusu) } \times \\
10.000\end{array}$ & $\begin{array}{l}\text { - İlçe Kaymakamlığı } \\
\text { - TÜIKK }\end{array}$ & Kullanılmadi \\
\hline 5 & $\begin{array}{l}\text { Bin Kişi Başına Düşen } \\
\text { Günlük Yerel Gazete } \\
\text { Tirajı }\end{array}$ & GGT & (Günlük gazete tirajı $/ 6+$ nüfus $) \times 1.000$ & $\begin{array}{l}\text { - İlçe Kaymakamlığı } \\
\text { - TÜİK }\end{array}$ & Kullanıld 1 \\
\hline 6 & $\begin{array}{l}\text { Bin Kişi Başına Düşen } \\
\text { Aylık Yerel Dergi Tirajı }\end{array}$ & ADT & (Aylık dergi tiraj1 $/ 6+$ nüfus) $\times 1.000$ & $\begin{array}{l}\text { - İlçe Kaymakamlığı } \\
\text { - TÜİK }\end{array}$ & Kullanılmadı \\
\hline 7 & $\begin{array}{l}\text { Elektrik Kayıp / Kaçak } \\
\text { Oranı }\end{array}$ & EKKO & $\begin{array}{l}\text { (Tüketilen elektrik miktarı (kwh) - Faturalanan } \\
\text { elektrik miktarı }(\mathrm{kwh})) \text { / Tüketilen elektrik miktarı } \\
(\mathrm{kwh})\end{array}$ & - MEPAŞ & Kullanıldı \\
\hline 8 & İntihar Oranı & İO & $\begin{array}{l}\text { Y1l içindeki intihar sayıs1 / Y1l içindeki toplam } \\
\text { ölüm sayısı }\end{array}$ & $\begin{array}{l}\text { - İlçe Emniyet } \\
\text { Müdürlüğü } \\
\text { - İlçe Jandarma } \\
\text { Komutanlığı } \\
\text { - İlçe Cumhuriyet } \\
\text { Başsavcılığı - TÜİK }\end{array}$ & Kullanıld 1 \\
\hline 9 & Suç Oranı & SO & Y1l içindeki suç sayıs1 / 2013 toplam nüfus & $\begin{array}{l}\text { - Konya İl Emniyet } \\
\text { Müdürlüğü } \\
\text { - İlçe Emniyet } \\
\text { Müdürlüğü } \\
\text { - İlçe Cumhuriyet } \\
\text { Başsavcılığı - TÜİK }\end{array}$ & Kullanıldı \\
\hline 10 & $\begin{array}{l}\text { Merkezi Yönetimde } \\
\text { Kadın Temsil Oranı }\end{array}$ & MYKTO & $\begin{array}{l}\text { İlçeden seçilen kadın milletvekili sayısı / İlçeden } \\
\text { seçilen milletvekili sayısı }\end{array}$ & $\begin{array}{l}\text { - TBMM } \\
\text { - Parti Teşkilatları }\end{array}$ & Kullanıldı \\
\hline 11 & $\begin{array}{l}\text { Yerel Yönetimlerde } \\
\text { Kadın Temsil Oranı }\end{array}$ & YYKTO & $\begin{array}{l}\text { (Seçilen kadın belediye başkanı sayısı+Seçilen } \\
\text { kadın belediye meclis üyesi sayısı)/ ( } 1+\text { Toplam } \\
\text { belediye meclis üyesi sayısı) }\end{array}$ & - İlçe Belediyeleri & Kullanıldı \\
\hline 12 & Güven Oranı & $\mathrm{GO}$ & Anket değerleri & - İlçede yaşayan halk & Kullanılmadı \\
\hline 13 & Kaba Boşanma Hızı & $\mathrm{KBH}$ & (Boşanan sayıs1 / 15+ nüfus) $\times 1.000$ & - TÜİK & Kullanıld1 1 \\
\hline 14 & $\begin{array}{l}\text { Bin Kişi Başına Düşen } \\
\text { Dernek Sayısı }\end{array}$ & DS & (Dernek sayıs1 $/ 15+$ nüfus $) \times 1.000$ & $\begin{array}{l}\text { - Konya Valiliği } \\
\text { Dernekler İl Müdürlüğü } \\
\text { - Karaman Valiliği } \\
\text { Dernekler İl Müdürlüğü } \\
\text { - TÜİK }\end{array}$ & Kullanıldı \\
\hline 15 & $\begin{array}{l}\text { Bin Kişi Başına Düşen } \\
\text { Vakıf Sayısı }\end{array}$ & VS & $($ Vakıf sayıs1 $/ 15+$ nüfus $) \times 1.000$ & $\begin{array}{l}\text { - Konya Vakıflar Bölge } \\
\text { Müdürlüğü } \\
\text { - TÜİK }\end{array}$ & Kullanıldı \\
\hline 16 & Net Göç Hizı & $\mathrm{NGH}$ & $\begin{array}{l}\text { Net göç / (İlçe son nüfusu }-(0,5 \times \text { Net göç })) \times \\
1.000\end{array}$ & - TÜIKK & Kullanıld 1 \\
\hline 17 & $\begin{array}{l}\text { Yerel Seçimlere Katılım } \\
\text { Oranı }\end{array}$ & YSKO & $\begin{array}{l}\text { Sandık seçmen listesinde yazılı seçmenlerin } \\
\text { toplam sayısı / Oy kullanan seçmenlerin toplam } \\
\text { sayısı }\end{array}$ & - TÜİK & Kullanıld 1 \\
\hline 18 & $\begin{array}{l}\text { Genel Seçimlere Katılım } \\
\text { Oranı }\end{array}$ & GSKO & $\begin{array}{l}\text { Sandık seçmen listesinde yazılı seçmenlerin } \\
\text { toplam sayısı / Oy kullanan seçmenlerin toplam } \\
\text { sayısı }\end{array}$ & - TÜİK & Kullanılmadı \\
\hline
\end{tabular}


Temel bileşenler analizinin anlamlı sonuçlar verebilmesi için değişken sayısı yapılan çalışmanın içeriğine göre değişmekle birlikte, genel olarak gözlem/değiş̧ken oranının yaklaşık 3:1 ya da 5:1 oranlarında olması genel kabul görmektedir (Tüysüz, 2011: 101). Çalışmamızda temel bileşenler analizinde kullanılabilen değişken sayısı 12 ve gözlem sayısı 37'dir. Bu sayılar, çalışmamızda kullanılan gözlem/değişken oranının temel bileşenler analizinde önerilen aralığa uygun olduğunu göstermektedir.

Yukarıda detayları aktarılan 18 sosyal sermaye göstergesi, notasyonları, hesaplama yöntemi ve veri kaynağı bilgileri Tablo: 4'te özetlenmiştir.

\subsection{Araştırmanın Bulguları}

Araştırmamızda kullanılan değişkenlere ait tanımlayıcı istatistikler Tablo: 5'te gösterilmiştir.

Tablo: 5

Değişkenlere Ait Tanımlayıcı İstatistikler

\begin{tabular}{|l|r|r|r|r|}
\hline \multicolumn{1}{|c|}{ Değişken } & En Küçük & En Büyük & Ortalama & Standart Sapma \\
\hline Bin Kişi Başına Düşen Yeni Girişimci Sayısı &,- 75 & 3,95 & 1,0875 & 1,00208 \\
\hline Kadın İstihdam Oranı &, 08 &, 29 &, 1494 &, 04848 \\
\hline Vergi Tahsilat / Tahakkuk Oranı &, 22 &, 99 &, 6774 &, 15357 \\
\hline Onbin Kişi Başına Düşen Sinema Sayısı &, 00 &, 78 &, 0403 &, 13854 \\
\hline Bin Kişi Başına Düşen Günlük Yerel Gazete Tirajı &, 00 & 36,11 & 5,6395 & 7,71145 \\
\hline Bin Kişi Başına Düşn Aylık Yerel Dergi Tirajı &, 00 & 80,99 & 4,5063 & 15,49688 \\
\hline Elektrik Kayıp / Kaçak Oranı &, 01 &, 11 &, 0691 &, 01647 \\
\hline İntihar Oranı &, 00 &, 14 &, 0201 &, 03386 \\
\hline Suç Oranı &, 00 &, 05 &, 0133 &, 01138 \\
\hline Merkezi Yönetimde Kadın Temsil Oranı &, 00 &, 50 &, 0225 &, 09752 \\
\hline Yerel Yönetimlerde Kadın Temsil Oranı &, 00 &, 18 &, 0478 &, 06017 \\
\hline Güven Oranı &, 16 &, 93 &, 5977 &, 15533 \\
\hline Kaba Boşanma Hızı & 11,84 & 44,63 & 22,1458 & 7,65073 \\
\hline Bin Kişi Başına Düş̧en Dernek Sayısı &, 63 & 3,17 & 1,5764 &, 59284 \\
\hline Bin Kişi Başına Düşen Vakıf Sayısı &, 02 &, 63 &, 1331 &, 11684 \\
\hline Net Göç Hızı & $-71,54$ & 36,87 & $-6,3849$ & 24,33655 \\
\hline Yerel Seçimlere Katılım Oranı &, 74 &, 97 &, 9034 &, 05062 \\
\hline Genel Seçimlere Katılım Oranı &, 67 &, 93 &, 8568 &, 05963 \\
\hline
\end{tabular}

Tablo: 5'te görüleceği üzere 37 ilçeye ait bin kişi başına düşen yeni girişimci sayıs1 ortalamas1 1,0875 iken kadın istihdam oranı ortalamas1 \%14,94'tür. Vergi tahsilat/tahakkuk oranı ortalaması \%67,74 iken onbin kişi başına düşen sinema sayısı ortalaması 0,0403 olarak bulunmuştur. Bin kişi başına düşen günlük yerel gazete tiraj1 5,6395 iken bin kişi başına düşen aylık yerel dergi tiraj1 4,5063'tür. Elektrik kayıp/kaçak 
oranı ortalaması $\% 6,91$ iken intihar oranı ortalaması $\% 2,01$ ve suç oranı ortalaması $\% 1,33$ 'tür. Merkezi yönetimde kadın temsil oranı ortalaması \%2,25 iken yerel yönetimlerde kadın temsil oranı ortalaması \%4,78'dir. Güven oranı ortalaması 37 ilçe için \%59,77 olarak bulunmuşken kaba boşanma hızı ortalaması 22,1458'dir. Bin kişi başına düşen dernek sayısı ortalaması 1,5764 iken bin kişi başına düşen vakıf sayısı ortalaması 0,1331'dir. Net göç hızı ortalamasının -6,3849, yerel seçimlere katılım oranı ortalamasının \%90,34 ve genel seçimlere katılım oranı ortalamasının \%85,68 olduğu görülmektedir.

Temel bileşenler analizi kapsamına alınan 12 değişkenle ilgili hesaplanan temel bileşenlerin öz değerleri ve açıklama oranları Tablo: 6'da gösterilmiştir.

Tablo: 6

Temel Bileşenlerin Özdeğerleri

\begin{tabular}{|c|c|c|c|c|c|c|}
\hline \multirow[b]{2}{*}{ Bileşen } & \multicolumn{3}{|c|}{ Özdeğerler (Eigenvalues) } & \multicolumn{3}{|c|}{ Yük Kareleri } \\
\hline & Toplam & $\begin{array}{c}\text { Varyans } \\
\text { Açıklama Oranı } \\
(\%)\end{array}$ & $\begin{array}{c}\text { Birikimli Varyans } \\
\text { Açıklama Oranı } \\
(\%)\end{array}$ & Toplam & $\begin{array}{c}\text { Varyans } \\
\text { Açıklama Oranı } \\
(\%)\end{array}$ & $\begin{array}{c}\text { Birikimli Varyans } \\
\text { Açıklama Oranı } \\
(\%)\end{array}$ \\
\hline 1 & 2,829 & 23,571 & 23,571 & 2,829 & 23,571 & 23,571 \\
\hline 2 & 1,885 & 15,704 & 39,276 & 1,885 & 15,704 & 39,276 \\
\hline 3 & 1,438 & 11,980 & 51,255 & 1,438 & 11,980 & 51,255 \\
\hline 4 & 1,259 & 10,493 & 61,748 & 1,259 & 10,493 & 61,748 \\
\hline 5 & 1,141 & 9,508 & 71,257 & 1,141 & 9,508 & 71,257 \\
\hline 6 & ,927 & 7,726 & 78,983 & & & \\
\hline 7 & 670 & 5,587 & 84,570 & & & \\
\hline 8 & ,547 & 4,559 & 89,129 & & & \\
\hline 9 & ,410 & 3,415 & 92,545 & & & \\
\hline 10 & 387 & 3,225 & 95,770 & & & \\
\hline 11 & 271 & 2,257 & 98,026 & & & \\
\hline 12 & 237 & 1,974 & 100,000 & & & \\
\hline
\end{tabular}

Analiz kapsamında önemli bulunan bileşen sayısı hakkındaki bilgiler Tablo 6'da incelendiğinde 12 göstergeden beşinin 1'den yüksek özdeğere sahip olduğu görülmektedir. Dolayısıyla önemli bileşen sayısı 5 'tir. Birinci temel bileşen toplam varyansın \%23,571'ini açıklarken, beş bileşen toplam varyansın \%71,257'sini açıklamaktadır. $\mathrm{Bu}$ oran, 12 göstergeden oluşan orijinal değişken setinin beş bileşen ile yaklaşık \%71 oranında temsil edilebileceğini göstermektedir ve istatistiksel açıdan yeterlidir. Tablo: 7'de temel bileşenler yük matrisi bulunmaktadır. 
Tablo: 7

Temel Bileșenler Yük Matrisi

\begin{tabular}{|c|c|c|c|c|c|c|}
\hline Nu. & Gösterge & $\mathbf{1}$ & 2 & 3 & 4 & 5 \\
\hline 1 & Vergi Tahsilat / Tahakkuk Oranı &,- 171 & 240 & ,410 &,- 582 & ,452 \\
\hline 2 & Bin Kiși Başına Düșen Günlük Yerel Gazete Tiraj1 &, 875 & ,043 &, 021 & 000 &,- 200 \\
\hline 3 & Elektrik Kayıp / Kaçak Oranı &, 082 & ,665 &, 162 &, 043 & 379 \\
\hline 4 & İntihar Oranı & ,101 &,- 128 &,- 395 &, 042 &, 739 \\
\hline 5 & Suç Oranı & ,645 & ,332 &,- 168 &,- 068 &,- 035 \\
\hline 6 & Merkezi Yönetimde Kadın Temsil Oranı & ,304 &,- 279 &,- 182 & ,442 & ,343 \\
\hline 7 & Yerel Yönetimlerde Kadın Temsil Oranı & 857 &,- 094 & ,103 &, 084 &,- 064 \\
\hline 8 & Kaba Boşanma Hızı & 461 &,- 558 & ,256 &,- 398 & 019 \\
\hline 9 & Bin Kişi Başına Düşen Dernek Sayısı & 144 &,- 001 & 487 & ,682 & 184 \\
\hline 10 & Bin Kişi Başına Düşen Vakıf Sayısı &,- 401 & 145 & ,649 & 247 &,- 117 \\
\hline 11 & Net Göç Hızı & ,592 & ,583 & ,248 &,- 112 & 010 \\
\hline 12 & Yerel Seçimlere Katılım Oranı &,- 166 & ,705 &,- 478 &, 111 &,- 191 \\
\hline
\end{tabular}

Temel bileşenler yük matrisi, hangi orijinal değişkenin (göstergenin) hangi bileşen üzerinde ne kadar ağırlığı olduğunu gösterir. Tablo 7'de görülen temel bileşenler yük matrisi değerlerine göre, birinci temel bileşende yer alan 9 değişken sosyal sermaye ile aynı yönde ilişkiye sahipken 3 değişken sosyal sermaye ile zit yönde ilişkiye sahiptir. Örneğin birinci temel bileşende bin kişi başına düşen günlük yerel gazete tirajı pozitif yönlü ilişkiye sahipken vergi tahsilat/tahakkuk oranı negatif yönlü ilişkiye sahip görülmektedir. Birinci bileşen içerisinde mutlak değer olarak en büyük öneme sahip üç değişken sırasıyla; bin kişi başına düşen günlük yerel gazete tirajı, yerel yönetimlerde kadın temsil oranı ve suç oranıdır.

İkinci temel bileşende yer alan değerler incelendiğinde ise 7 değişken sosyal sermaye ile aynı yönde ilişkiye sahipken 5 değişken sosyal sermaye ile zıt yönde ilişkiye sahip görülmektedir. İkinci temel bileşene örnek olarak yerel seçimlere katılım oranı pozitif yönde ilişskiye sahipken intihar oranı negatif yönlü ilişkiye sahip görülmektedir. İkinci bileşen içerisinde mutlak değer olarak en büyük öneme sahip üç değişken sırasıyla; yerel seçimlere katılım oranı, elektrik kayıp/kaçak oranı ve net göç hızıdır.

Üçüncü temel bileşende yer alan değerler incelendiğinde 8 değişken sosyal sermaye ile aynı yönde ilişkiye sahipken 4 değişken sosyal sermaye ile zıt yönde ilişkiye sahip görülmektedir. Üçüncü temel bileşene örnek olarak vergi tahsilat/tahakkuk oranı pozitif yönde ilişkiye sahipken suç oranı negatif yönlü ilişkiye sahip görülmektedir. Üçüncü bileşen içerisinde mutlak değer olarak en büyük öneme sahip üç değişken sırasıyla; bin kişi başına düşen vakıf sayısı, bin kişi başına düşen dernek sayısı ve yerel seçimlere katılım oranıdır. 
Tablo: 8

Bileșenlere Ait Endeks Değerleri

\begin{tabular}{|c|c|c|c|c|c|}
\hline & Y1 & Y2 & Y3 & Y4 & Y5 \\
\hline Ahırlı & $-6,147534923$ & $-19,35364677$ & $-0,71204629$ & $-2,526386291$ & 0,575403515 \\
\hline Akören & $-4,263585986$ & $-22,9976105$ & $-0,074856542$ & $-4,894343726$ & 0,427114642 \\
\hline Akșehir & 23,35947009 & $-19,16438127$ & 6,521264342 & $-10,2070413$ & $-2,407774324$ \\
\hline Altınekin & 16,06516468 & 4,23838786 & 8,099913276 & $-6,463455286$ & 0,945626945 \\
\hline Beyşehir & 26,70515081 & $-3,527526362$ & 7,603788621 & $-5,926469287$ & $-2,045675968$ \\
\hline Bozkır & $-3,694390769$ & $-26,14087392$ & $-1,144671432$ & $-4,123803129$ & $-0,250403074$ \\
\hline Cihanbeyli & 10,20305636 & $-31,57595612$ & 6,031438786 & $-13,15203726$ & 0,519235998 \\
\hline Çeltik & 10,5582914 & $-21,84562261$ & 7,188549865 & $-11,39170128$ & 0,956288304 \\
\hline Çumra & 20,41487191 & $-4,392806173$ & 7,3199741 & $-7,507012247$ & $-0,851094467$ \\
\hline Derbent & $-2,309643525$ & $-17,04467515$ & 0,44795582 & $-3,734303265$ & 0,289598058 \\
\hline Derebucak & $-24,18189596$ & $-48,65991307$ & $-7,353101992$ & $-2,386622398$ & 0,571896436 \\
\hline Doğanhisar & $-11,37467731$ & $-31,99806418$ & $-3,715317972$ & -2,521093959 & $-0,012741439$ \\
\hline Emirgazi & $-1,643965475$ & $-14,98147259$ & 58764541 & $-4,155382393$ & 0,474641247 \\
\hline Ereğli & 31,06870957 & $-13,55183884$ & 10,64568836 & $-13,22038962$ & $-1,786846531$ \\
\hline Güneysınır & $-0,356024418$ & 7078984 & 1,579355849 & $-4,452806801$ & 0,580913552 \\
\hline Hadim & $-34,68759035$ & 0825155 & $-12,77037857$ & 2,961567328 & $-0,062779017$ \\
\hline Halkapınar & 1739 & 4734 & 674895 & 272717 & 490122 \\
\hline Hüyük & 4293 & 2735 & 3094 & 14199 & $\overline{01792076}$ \\
\hline Ilgın & 8,404108845 & 517449 & 895496 & $-5,955143544$ & $-0,791604068$ \\
\hline Kadınhanı & 8,530398048 & $-8,217588508$ & 3,821360729 & $-5,216593978$ & $-0,019015788$ \\
\hline Karapınar & 8889204 & 8564238 & 6,913029211 & $-6,748479681$ & $-0,001412655$ \\
\hline Karatay & 555448 & 5721983 & 7126247 & $-12,97721723$ & $-2,150535676$ \\
\hline Kulu & 5362062 & $-14,72315845$ & 5770029 & $-19,10118766$ & $-0,484919544$ \\
\hline Meram & 42,98872977 & $-0,798664288$ & 14,20238938 & $-12,68845112$ & $-2,485265417$ \\
\hline Sarayönü & 16,66806932 & $-7,068407529$ & 7,733650459 & $-6,810925901$ & 0,126290341 \\
\hline Selçuklu & 58,28547067 & 0,369448804 & 14,24704822 & $-12,87058037$ & $-6,109303624$ \\
\hline Seydișehir & 14,02344086 & $-9,794436359$ & 6,059090053 & $-6,439315158$ & $-0,191032955$ \\
\hline Taşkent & 18,17127668 & 2,301757553 & 9,539668602 & $-7,585517694$ & 1,003699691 \\
\hline Tuzlukçu & 0,891918008 & $-16,39486855$ & 2,073472474 & $-5,392941833$ & 0,563689515 \\
\hline Yalıhüyük & 24,51969299 & 2,086797431 & 13,63734644 & $-9,81232446$ & 1,427511729 \\
\hline Yunak & $-1,146119409$ & $-30,78200992$ & 1,098996945 & $-7,521544298$ & 0,219202351 \\
\hline Ayrancı & 4,045917736 & $-18,46706727$ & 3,587499105 & $-7,716684246$ & 0,651924695 \\
\hline Başyayla & $-8,921804603$ & $-21,56957748$ & $-2,012862068$ & $-1,182607332$ & 0,372156368 \\
\hline Ermenek & 16,48550892 & $-8,730109221$ & 5,606634526 & $-6,402866382$ & $-0,898519066$ \\
\hline Kazımkarabekir & 12,88813264 & $-11,2320064$ & 7,753882269 & $-9,368785618$ & 0,882645384 \\
\hline Karaman Merkez & 30,44394842 & $-9,599432933$ & 12,66388818 & $-13,53583988$ & $-0,436914065$ \\
\hline Sarıveliler & 32,09492615 & 13,63637053 & 11,8369969 & $-7,71630081$ & $-0,768252219$ \\
\hline
\end{tabular}

Dördüncü temel bileşende yer alan değerler incelendiğinde 8 değişken sosyal sermaye ile aynı yönde ilişkiye sahipken 4 değişken sosyal sermaye ile zıt yönde ilişkiye sahip görülmektedir. Dördüncü temel bileşene örnek olarak merkezi yönetimde kadın temsil oranı pozitif yönde ilişkiye sahipken suç oranı negatif yönlü ilişkiye sahip görülmektedir. 
Dördüncü bileşen içerisinde mutlak değer olarak en büyük öneme sahip üç değişken sırasıyla; bin kişi başına düşen dernek sayısı, vergi tahsilat/tahakkuk oranı ve merkezi yönetimde kadın temsil oranıdır.

Beşinci ve son temel bileşende yer alan değerler incelendiğinde 7 değişken sosyal sermaye ile aynı yönde ilişkiye sahipken 5 değişken sosyal sermaye ile zıt yönde ilişkiye sahip görülmektedir. Beşinci temel bileşene örnek olarak vergi tahsilat/tahakkuk oranı pozitif yönde ilişkiye sahipken bin kişi başına düşen vakıf sayısı negatif yönlü ilişkiye sahip görülmektedir. Beşinci bileşen içerisinde mutlak değer olarak en büyük öneme sahip üç değişken sırasıyla; intihar oranı, vergi tahsilat/tahakkuk oranı ve elektrik kayıp/kaçak oranıdir.

Tablo: 7'de verilmiş olan her bir değişkene ilişkin bileşen katsayıları gösterge değerleriyle çarpılıp her ilçe için beş bileşene ait endeks değerleri elde edilmiştir. Bileşenlere ait endeks değerleri Tablo: 8'de gösterilmiştir.

Özdeğerleri birden büyük beş temel bileşen, varyans açıklama oranları esas alınarak ağırlıkları toplamı 1 olacak şekilde ağırlıklandırılmış ve nihai değişken olan sosyal sermaye endeks değerleri elde edilmiştir.

Sosyal Sermaye Endeksi $i_{i}=(23,571 / 71,257)\left(Y_{1}\right)+(15,704 / 71,257)\left(Y_{2}\right)+$ $(11,980 / 71,257)\left(\mathrm{Y}_{3}\right)+(10,493 / 71,257)\left(\mathrm{Y}_{4}\right)+(9,508 / 71,257)\left(\mathrm{Y}_{5}\right)$

Sosyal Sermaye Endeksi $i_{i}=(0,330788554)\left(\mathrm{Y}_{1}\right)+(0,220385366)\left(\mathrm{Y}_{2}\right)+$ $(0,168123833)\left(\mathrm{Y}_{3}\right)+(0,147255708)\left(\mathrm{Y}_{4}\right)+(0,133432505)\left(\mathrm{Y}_{5}\right)$

$$
\begin{gathered}
\mathbf{Y}_{1}=\left[-0,171\left(\mathrm{z}_{1}\right)+0,875\left(\mathrm{z}_{2}\right)+0,082\left(\mathrm{z}_{3}\right)+0,101\left(\mathrm{z}_{4}\right)+0,645\left(\mathrm{z}_{5}\right)+0,304\left(\mathrm{z}_{6}\right)\right. \\
\left.+0,857\left(\mathrm{z}_{7}\right)+0,461\left(\mathrm{z}_{8}\right)+0,144\left(\mathrm{z}_{9}\right)-0,401\left(\mathrm{z}_{10}\right)+0,592\left(\mathrm{z}_{11}\right)-0,166\left(\mathrm{z}_{12}\right)\right] \\
\mathbf{Y}_{\mathbf{2}}=\left[0,240\left(\mathrm{z}_{1}\right)+0,043\left(\mathrm{z}_{2}\right)+0,665\left(\mathrm{z}_{3}\right)-0,128\left(\mathrm{z}_{4}\right)+0,332\left(\mathrm{z}_{5}\right)-0,279\left(\mathrm{z}_{6}\right)-\right. \\
\left.0,094\left(\mathrm{z}_{7}\right)-0,558\left(\mathrm{z}_{8}\right)-0,001\left(\mathrm{z}_{9}\right)+0,145\left(\mathrm{z}_{10}\right)+0,583\left(\mathrm{z}_{11}\right)+0,705\left(\mathrm{z}_{12}\right)\right] \\
\mathbf{Y}_{\mathbf{3}}=\left[0,410\left(\mathrm{z}_{1}\right)+0,021\left(\mathrm{z}_{2}\right)+0,162\left(\mathrm{z}_{3}\right)-0,395\left(\mathrm{z}_{4}\right)-0,168\left(\mathrm{z}_{5}\right)-0,182\left(\mathrm{z}_{6}\right)+\right. \\
\left.0,103\left(\mathrm{z}_{7}\right)+0,256\left(\mathrm{z}_{8}\right)+0,487\left(\mathrm{z}_{9}\right)+0,649\left(\mathrm{z}_{10}\right)+0,248\left(\mathrm{z}_{11}\right)-0,478\left(\mathrm{z}_{12}\right)\right] \\
\left.+0,084\left(\mathrm{z}_{7}\right)-0,398\left(\mathrm{z}_{8}\right)+0,682\left(\mathrm{z}_{9}\right)+0,247\left(\mathrm{z}_{10}\right)-0,112\left(\mathrm{z}_{11}\right)+0,111\left(\mathrm{z}_{12}\right)\right] \\
\mathbf{Y}_{4}=\left[-0,582\left(\mathrm{z}_{1}\right)+0,000\left(\mathrm{z}_{2}\right)+0,043\left(\mathrm{z}_{3}\right)+0,042\left(\mathrm{z}_{4}\right)-0,068\left(\mathrm{z}_{5}\right)+0,442\left(\mathrm{z}_{6}\right)\right. \\
\mathbf{Y}_{\mathbf{5}}=\left[0,452\left(\mathrm{z}_{1}\right)-0,200\left(\mathrm{z}_{2}\right)+0,379\left(\mathrm{z}_{3}\right)+0,739\left(\mathrm{z}_{4}\right)-0,035\left(\mathrm{z}_{5}\right)+0,343\left(\mathrm{z}_{6}\right)-\right. \\
\left.0,064\left(\mathrm{z}_{7}\right)+0,019\left(\mathrm{z}_{8}\right)+0,184\left(\mathrm{z}_{9}\right)-0,117\left(\mathrm{z}_{10}\right)+0,010\left(\mathrm{z}_{11}\right)-0,191\left(\mathrm{z}_{12}\right)\right]
\end{gathered}
$$


Kullanılan Notasyonların Anlamları:

i : $1,2, \ldots, 37$ ilçe

$\mathrm{Z}_{\mathrm{i}}: 1,2, \ldots, 12$ değişken

Yapılan hesaplamalar sonucunda her bir ilçe için tespit edilen sosyal sermaye endeks değerleri Tablo: 9'da gösterilmiştir.

Tablo: 9

\section{İlçelerin Sosyal Sermaye Endeks Değerleri}

\begin{tabular}{|c|l|r|c|l|r|}
\hline Sira & \multicolumn{1}{|c|}{ İlçe } & $\begin{array}{c}\text { Sosyal Sermaye Endeks } \\
\text { Değeri }\end{array}$ & Sira & \multicolumn{1}{|c|}{ İlçe } & $\begin{array}{c}\text { Sosyal Sermaye Endeks } \\
\text { Değeri }\end{array}$ \\
\hline $\mathbf{1}$ & Selçuklu & 19,04640993 & $\mathbf{2 1}$ & Çeltik & $-1,663220117$ \\
\hline $\mathbf{2}$ & Karatay & 18,79781078 & $\mathbf{2 2}$ & Ayranc1 & $-3,177721851$ \\
\hline $\mathbf{3}$ & Sarıveliler & 14,37319286 & $\mathbf{2 3}$ & Tuzlukçu & $-3,688479656$ \\
\hline $\mathbf{4}$ & Meram & 14,23186394 & $\mathbf{2 4}$ & Güneysınır & $-4,060350953$ \\
\hline $\mathbf{5}$ & Yalıüyük & 9,609052046 & $\mathbf{2 5}$ & Emirgazi & $-4,283319464$ \\
\hline $\mathbf{6}$ & Kulu & 9,11526143 & $\mathbf{2 6}$ & Cihanbeyli & $-4,437225364$ \\
\hline $\mathbf{7}$ & Beyşehir & 8,189055027 & $\mathbf{2 7}$ & Derbent & $-4,956344235$ \\
\hline $\mathbf{8}$ & Karaman Merkez & 8,032508342 & $\mathbf{2 8}$ & Ahırlı & $-6,713753931$ \\
\hline $\mathbf{9}$ & Taşkent & 7,138885059 & $\mathbf{2 9}$ & Akören & $-7,154996487$ \\
\hline $\mathbf{1 0}$ & Erĕgli & 6,895139252 & $\mathbf{3 0}$ & Bozkır & $-7,816240246$ \\
\hline $\mathbf{1 1}$ & Altınekin & 6,784436411 & $\mathbf{3 1}$ & Hüyük & $-7,817578075$ \\
\hline $\mathbf{1 2}$ & Çumra & 5,796543801 & $\mathbf{3 2}$ & Yunak & $-8,056601728$ \\
\hline $\mathbf{1 3}$ & Karapınar & 5,193163937 & $\mathbf{3 3}$ & Başyayla & $-8,167748076$ \\
\hline $\mathbf{1 4}$ & Sarayönü & 4,269947453 & $\mathbf{3 4}$ & Doğanhisar & $-11,81209723$ \\
\hline $\mathbf{1 5}$ & Ermenek & 3,409087963 & $\mathbf{3 5}$ & Halkapınar & $-13,17844393$ \\
\hline $\mathbf{1 6}$ & Akşehir & 2,775555669 & $\mathbf{3 6}$ & Derebucak & $-20,23439303$ \\
\hline $\mathbf{1 7}$ & Seydişehir & 2,525204814 & $\mathbf{3 7}$ & Hadim & $-24,23665726$ \\
\hline $\mathbf{1 8}$ & Kazımkarabekir & 1,829655757 & & & \\
\hline $\mathbf{1 9}$ & Kadınhanı & 0,882473038 & & & \\
\hline $\mathbf{2 0}$ & Ilgın & $-1,522134461$ & & & \\
\hline
\end{tabular}

Tablo: 9'daki sosyal sermaye endeks değerleri incelendiğinde, Konya ve Karaman'a bağlı 37 ilçe içerisinde en yüksek sosyal sermaye seviyesine sahip ilçe Selçuklu iken, bunu sırasıyla Karatay, Sarıveliler, Meram, Yalıhüyük, Kulu, Beyşehir, Karaman merkez, Taşkent ve Ereğli takip etmektedir. En düşük sosyal sermaye seviyesine sahip ilçe Hadim iken, bunu sırasıyla Derebucak, Halkapınar, Doğanhisar, Başyayla ve Yunak takip etmektedir. 


\subsection{Sosyal Sermaye Bağlamında İlçelerin Gruplandırılması}

Hesaplamalar sonucunda elde edilen ilçelerin sosyal sermaye değerleri esas alınmak suretiyle Konya ve Karaman'ın ilçeleri (37 ilçe), kırılma noktaları tespit edilerek 5 gruba ayrılmıştır. Elde edilen gruplar Tablo 10:'da gösterilmiştir.

Tablo: 10

İlçelerin Sosyal Sermaye Grupları

\begin{tabular}{|c|c|c|c|c|c|}
\hline Grup & $\begin{array}{c}\text { Değer } \\
\text { Aralığı (Üst } \\
\text { Değer) }\end{array}$ & $\begin{array}{c}\text { Değer } \\
\text { Aralığı (Alt } \\
\text { Değer) }\end{array}$ & $\begin{array}{l}\text { Gruptaki } \\
\text { İlçe Sayısı }\end{array}$ & İlçeler & $\begin{array}{c}\text { Şekil 1 } \\
\text { Haritasındaki } \\
\text { Renk } \\
\end{array}$ \\
\hline $\begin{array}{l}1 . \\
\text { Grup } \\
\end{array}$ & 19,04641 & 10,3898 & 4 & Selçuklu, Karatay, Sarıveliler, Meram & Açık kahverengi \\
\hline $\begin{array}{l}2 . \\
\text { Grup }\end{array}$ & 10,3898 & 1,733183 & 14 & $\begin{array}{l}\text { Yalıhüyük, Kulu, Beyşehir, Karaman } \\
\text { Merkez, Taşkent, Ereğli, Altınekin, } \\
\text { Çumra, Karapınar, Sarayönü, Ermenek, } \\
\text { Akşehir, Seydişehir, Kazımkarabekir }\end{array}$ & Turuncu \\
\hline $\begin{array}{c}3 . \\
\text { Grup }\end{array}$ & 1,733183 & $-6,92343$ & 10 & $\begin{array}{l}\text { Kadınhanı, Ilgın, Çeltik, Ayrancı, } \\
\text { Tuzlukçu, Güneysınır, Emirgazi, } \\
\text { Cihanbeyli, Derbent, Ahırlı }\end{array}$ & Sarı \\
\hline $\begin{array}{c}4 . \\
\text { Grup } \\
\end{array}$ & $-6,92343$ & $-15,58$ & 7 & $\begin{array}{l}\text { Akören, Bozkır, Hüyük, Yunak, } \\
\text { Başyayla, Doğanhisar, Halkapınar }\end{array}$ & Yeşil \\
\hline $\begin{array}{c}5 . \\
\text { Grup }\end{array}$ & $-15,58$ & $-24,2367$ & 2 & Derebucak, Hadim & Kırmızı \\
\hline
\end{tabular}

Tablo: 10'da yapılmış olan gruplandırma esas alınarak TR52 Düzey 2 Bölgesi'nin (Konya ve Karaman) ilçeler düzeyinde sosyal sermaye haritası düzenlenmiş ve Şekil: 1'de gösterilmiştir.

TR52 Düzey 2 Bölgesi (Konya ve Karaman illeri) sosyal sermaye haritası incelendiğinde 4 ilçenin yüksek düzeyde sosyal sermaye düzeyine sahip olduğu ve genel olarak yüksek sosyal sermaye düzeyi açısından bölge merkezinde bir yoğunlaşmanın olduğu göze çarpmaktadır. Burada şaşırtıcı olan veri, Sarıveliler ilçesinin en yüksek düzeyde sosyal sermaye düzeyine sahip olan 3. ilçe olmasıdır. Bu durumun, ilçenin kaba boşanma hızının son derece düşük olması ve net göç hızının çok yüksek olmasına bağlı olduğu düşünülmektedir.

Avrupa ülkelerinde genellikle kuzey bölgelerinin, güney bölgelerine nazaran sosyal sermaye düzeylerinin yüksek olması profilinin, ya da Türkiye'de batı bölgelerinin doğu bölgelerine nazaran daha yüksek sosyal sermaye düzeyine sahip olması profilinin araştırmamızda aynı yönde olmadığı görülmektedir. Her ne kadar dağılım biraz karışık 
görünse de, genel bir ayrım yapılmak istenirse, merkeze doğru yaklaştıkça sosyal sermaye düzeyinin yükseldiğini söyleyebiliriz.

\section{Şekil: 1}

\section{TR52 Düzey 2 Bölgesi (Konya ve Karaman) Sosyal Sermaye Haritası}

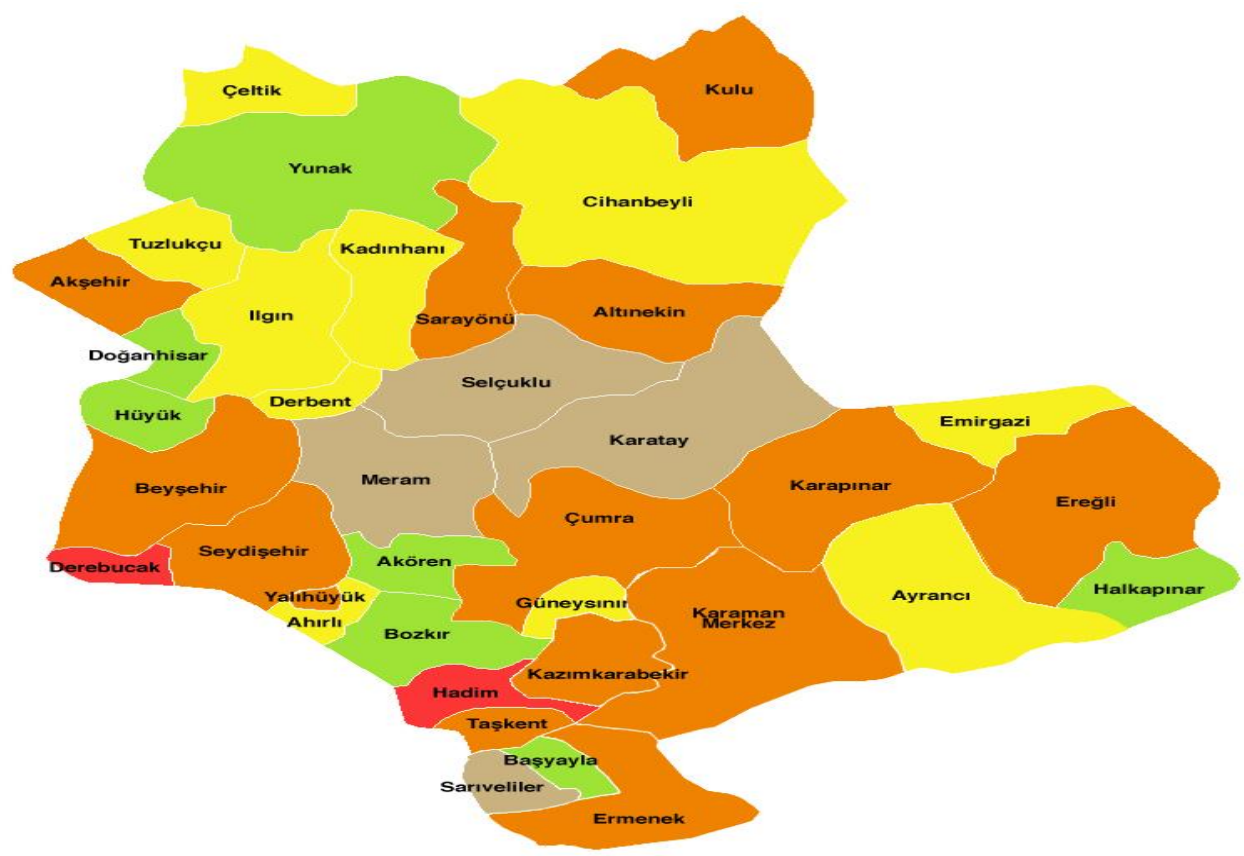

Sosyal sermaye düzeylerine yönelik yapılan bu gruplandırmayı, farklı bir şekilde Şekil: 2'deki gibi gösterebiliriz. Buna göre 4 ilçe sosyal sermayesi en yüksek ilçe iken, 14 ilçe sosyal sermayesi yüksek ilçeler grubuna alınmıştır. 10 ilçe sosyal sermayesi orta düzeydeki ilçeler grubunda iken, 7 ilçe sosyal sermayesi düşük ve 2 ilçe sosyal sermayesi en düşük grubuna dâhil edilmiştir. 
Şekil: 2

Sosyal Sermaye Düzeyine İlçelerin Gruplandırılması

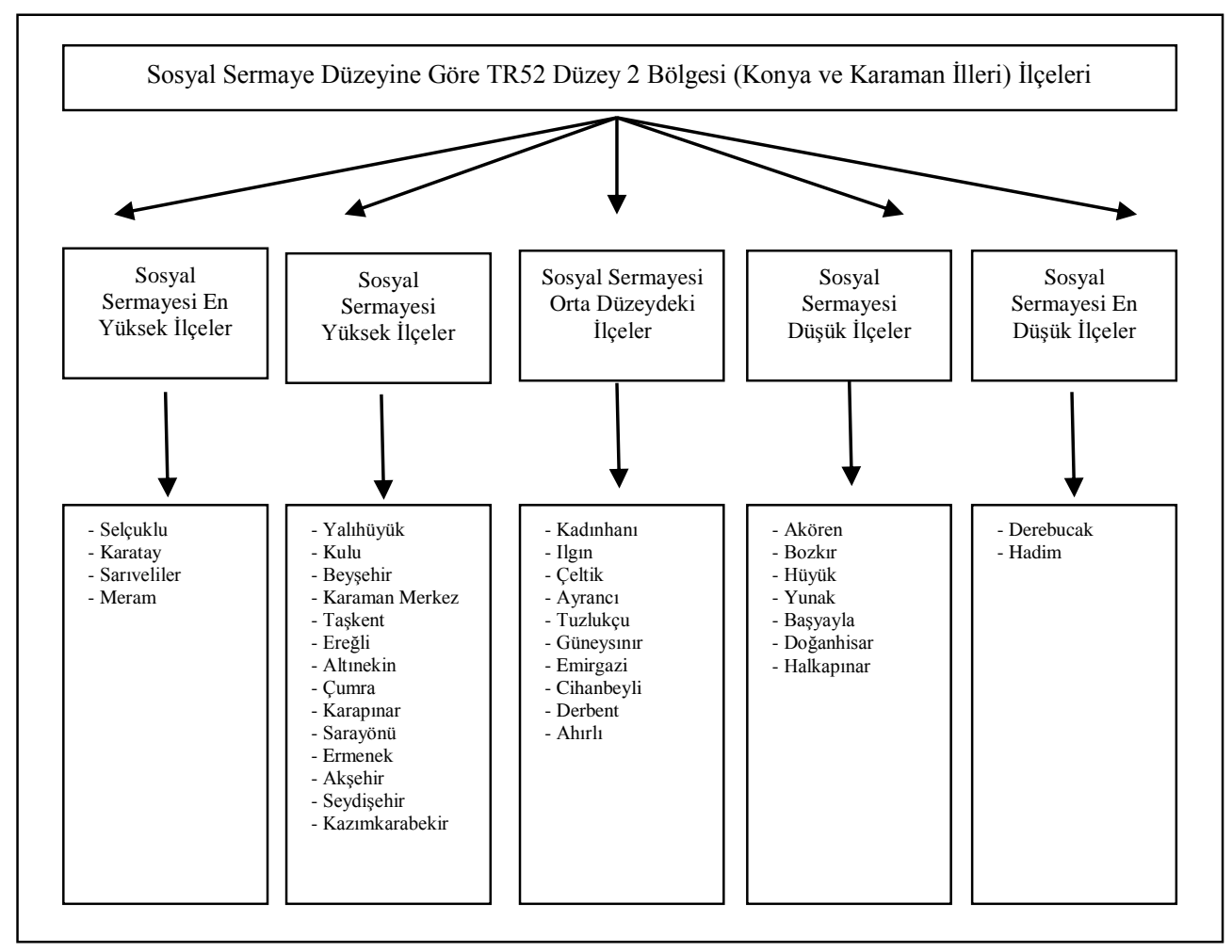

\subsection{Sosyal ve Ekonomik Gelişmişlik Endeks (SEGE) Sonuçlarıyla Karşılaştırma}

Araştırmada ilçelerin sosyal sermaye değerleriyle SEGE değerleri arasında anlamlı ilişki olup olmadığı test edilmiştir. Bu kapsamda 'Konya ve Karaman'ın ilçelerinin sosyal sermaye endeks değerleriyle SEGE (Sosyal ve Ekonomik Gelişmişlik Endeksi) değerleri arasında anlamlı bir ilişki vardır" hipotezini test edebilmek amacıyla Pearson İlişki Analizi yapılmıştır. İlçelerin hesaplanan sosyal sermaye endeks değerleri ve SEGE değerleri Tablo: 11'de, Pearson İlişki Analizi sonuçları Tablo: 12'de gösterilmiştir. 


\section{Tablo: 11}

\section{Hesaplanan Sosyal Sermaye Endeks Değerleri ve SEGE Değerleri}

\begin{tabular}{|c|c|c|c|c|}
\hline Sosyal Sermaye Değeri Sıra & İlçe & $\begin{array}{l}\text { Sosyal Sermaye } \\
\text { Endeks Değeri * }\end{array}$ & SEGE Değeri Sıra & SEGE Değeri ** \\
\hline 1 & Selçuklu & 19,04640993 & 1 & 62,07809 \\
\hline 2 & Karatay & 18,79781078 & 3 & 33,62205 \\
\hline 3 & Sarıveliler & 14,37319286 & 25 & $-7,31257$ \\
\hline 4 & Meram & 14,23186394 & 2 & 45,8147 \\
\hline 5 & Yalıhüyük & 9,609052046 & 35 & $-11,3686$ \\
\hline 6 & Kulu & 9,11526143 & 12 & 0,307589 \\
\hline 7 & Beyşehir & 8,189055027 & 9 & 3,357867 \\
\hline 8 & Karaman Merkez & 8,032508342 & 5 & 13,73063 \\
\hline 9 & Taşkent & 7,138885059 & 30 & $-10,196$ \\
\hline 10 & Ereğli & 6,895139252 & 4 & 15,06273 \\
\hline 11 & Altınekin & 6,784436411 & 19 & $-5,09582$ \\
\hline 12 & Çumra & 5,796543801 & 11 & 0,911496 \\
\hline 13 & Karapınar & 5,193163937 & 14 & $-0,61261$ \\
\hline 14 & Sarayönü & 4,269947453 & 18 & $-5,05946$ \\
\hline 15 & Ermenek & 3,409087963 & 22 & $-6,17977$ \\
\hline 16 & Akşehir & 2,775555669 & 6 & 8,721049 \\
\hline 17 & Seydişehir & 2,525204814 & 8 & 3,405671 \\
\hline 18 & Kazımkarabekir & 1,829655757 & 32 & $-10,6093$ \\
\hline 19 & Kadınhanı & 0,882473038 & 15 & $-3,61566$ \\
\hline 20 & Ilgin & $-1,522134461$ & 13 & $-0,40077$ \\
\hline 21 & Celtik & $-1,663220117$ & 27 & $-8,49093$ \\
\hline 22 & Ayranc1 & $-3,177721851$ & 7 & 5,846085 \\
\hline 23 & Tuzlukçu & $-3,688479656$ & 34 & $-10,9981$ \\
\hline 24 & Güneysınır & $-4,060350953$ & 23 & $-7,05803$ \\
\hline 25 & Emirgazi & $-4,283319464$ & 24 & $-7,18981$ \\
\hline 26 & Cihanbeyli & $-4,437225364$ & 10 & 0,933958 \\
\hline 27 & Derbent & $-4,956344235$ & 36 & $-11,6018$ \\
\hline 28 & Ahırlı & $-6,713753931$ & 33 & $-10,6981$ \\
\hline 29 & Akören & $-7,154996487$ & 29 & $-9,76726$ \\
\hline 30 & Bozkır & $-7,816240246$ & 21 & $-5,89125$ \\
\hline 31 & Hüyük & $-7,817578075$ & 28 & $-9,57877$ \\
\hline 32 & Yunak & $-8,056601728$ & 20 & $-5,43471$ \\
\hline 33 & Başyayla & $-8,167748076$ & 16 & $-3,74861$ \\
\hline 34 & Doğanhisar & $-11,81209723$ & 26 & $-7,71109$ \\
\hline 35 & Halkapınar & $-13,17844393$ & 31 & $-10,523$ \\
\hline 36 & Derebucak & $-20,23439303$ & 37 & $-12,8904$ \\
\hline 37 & Hadim & $-24,23665726$ & 17 & $-4,83532$ \\
\hline
\end{tabular}

* Sosyal sermaye endeks değerleri araştırmamız kapsamında hesaplanan 2013 yılına ait değerlerdir.

** SEGE değerleri 2012 yılına aittir. Kaynak: Buluş, Abdulkadir, Savaş Erdoğan ve Bilal Özel (2012). TR52 Bölgesi İlçeleri Sosyo-Ekonomik Gelişmişlik Endeksi, Mevlana Kalkinma Ajansı 2012 Teknik Destek Projesi Araştırma Raporu (TR52-12-TD01/045), Yararlanicı Kurum: Meram Belediyesi. 


\section{Tablo: 12}

\section{Hesaplanan Sosyal Sermaye Endeks Değerleri ve SEGE Değerleri Arasındaki Pearson İlişki Analizi}

\begin{tabular}{|l|r|r|}
\hline & Sosyal Sermaye Endeksi & \multicolumn{1}{|c|}{ SEGE Endeksi } \\
\hline Sosyal Sermaye Endeksi & 1,000 & $0,609 * *(\mathrm{p}=0,000)$ \\
\hline SEGE Endeksi & $0,609 * *(\mathrm{p}=0,000)$ & 1,000 \\
\hline
\end{tabular}

Tablo: 12 incelendiğinde, Konya ve Karaman'ın ilçeleri için elde edilen sosyal sermaye endeks değerleri ile SEGE değerleri arasındaki korelasyon katsayısı 0,609 olarak bulunmuş ve söz konusu değişkenler arasında \%1 önem düzeyinde istatistiksel olarak anlamlı olduğu görülmüsstür. Bu sonuçlara göre Konya ve Karaman'ın ilçeleri için sosyal sermaye endeks değerleri ile SEGE değerleri arasında paralellik olduğu görülmektedir. $\mathrm{Bu}$ iki değişken arasında bir neden sonuç ilişkisi olmamakla birlikte, sosyal sermaye endeks değerleriyle SEGE değerlerinin birlikte artıp azaldığı yorumu yapılabilir.

\section{Sonuç}

Fiziksel ve finansal sermaye unsurlarının gelişimine yönelik arayışlar, uzun yıllardır sosyoloji, iktisat, işletme gibi bilim dallarının inceleme alanı olmuştur. Ancak bu incelemeler, son yıllarda fiziksel ve finansal sermaye unsurları yerine bireyler ve gruplar arasındaki davranışları ön plana alan araştırmalara bırakmıştır. Özellikle son yıllarda araştırmacıların üzerinde durdukları önemli konulardan birisi de sosyal sermaye kavramı olmuştur. Entelektüel sermayeyi oluşturan ana kavramlardan birisi olarak kabul edilen sosyal sermaye, örgütsel ve toplumsal düzeyde yapılan araştırmalara konu olmaktadır. $\mathrm{Bu}$ bağlamda toplumsal düzeyde yapılan araştırmalar incelendiğinde, sosyal sermayenin ülkeler aras1, ülkeler, bölgeler ve iller düzeyinde incelendiği görülmektedir. Literatürde sıklıkla ülke, bölge ya da iller düzeyinde yapılmış olan sosyal sermayeye yönelik çalışmaların bir adım daha ileriye götürülerek ilçeler düzeyinde yapılması, bu araştırmanın özgün yönünü oluşturmaktadır. Türkiye örnekleminde sosyal sermaye konusunda yapılmış araştırmalar incelendiğinde, sosyal sermaye ölçümünü ilçeler düzeyine indirgeyen hiçbir çalışmaya rastlanmamıştır. Ancak sosyal sermaye düzeyinin ilçeler düzeyine indirgenmesi, illerin ve bölgelerin gelişmesi için mikro düzeyde yapılması gerekenlere yol gösterici bir nitelik taşıyacaktır. Türkiye'de ilçeler düzeyinde bu konuya gereken önemin verilmemiş olması, kayg1 vericidir.

Araştırma, bu kaygılardan yola çıkarak İstatistiki Bölge Sınıflandırmasına göre TR52 Düzey 2 bölgesi olarak tanımlanan Konya ve Karaman'ın ilçeler düzeyinde sosyal sermaye düzeylerini analiz etmeyi amaçlamıştır. Ayrıca araştırma, Konya'ya bağlı 31 ilçe ve Karaman'a bağlı 6 ilçe olmak üzere TR52 Düzey 2 bölgesinde bulunan 37 ilçe 
örnekleminde, sosyal sermaye düzeyiyle sosyal ve ekonomik gelişmişlik endeks düzeyleri arasında ilişki var mıdır sorusuna da kısıtlar ölçüsünde yanıt aramaktadır. Bu anlamda araştırmanın kısıtlarından ilki, araştırmada kullanılan sosyal sermaye göstergeleriyle ilgilidir. Araştırmada kullanılan sosyal sermaye göstergeleri, yapılan kapsamlı literatür taraması sonucunda tespit edilebilen göstergelerdir. Bunların dışında sosyal sermaye göstergeleri olarak kabul edilen ancak araştırmada kullanamadığımız göstergeler bulunmaktadır. Örneğin demokrasi oranı gibi. Bu gibi temininde sıkıntı yaşanacak göstergeler araştırmaya dâhil edilmemiş ve araştırmada kullanılan sosyal sermaye göstergeleri, araştırmacılar tarafından belirlenenlerle sınırlandırılmıştır. Dolayısıyla burada kullanılan sosyal sermaye gösterge sayıları artırılabilirdi. Araştırmanın ikinci kısıtı ise, Konya ve Karaman illerine bağlı ilçelerin 2013 yılı gösterge verileri esas alınarak değerlendirmelerin yapılmış olmasıdır. Aynı göstergelerin önceki yıllara ilişkin verileri de esas alınarak karşılaştırmalar yapmak, araştırmanın amacına anlamlı katkılar sağlayabilirdi. Ancak zaman ve maliyet gibi kısıtlar nedeniyle bunlar gerçekleştirilememiştir. Araştırmanın bir başka kısıtı ise, analizde kullanılmak üzere ilçelerden toplanan 18 değişkenden, KMO testi sonucunda 6 tanesinin analizlerde kullanılamamış olmasıdır. Özellikle bu 6 değişkenden birisi olan güven oranı değişkeninin tüm denemelere rağmen analize dâhil edilememiş olması (Bu değişkenin varlığı halinde KMO değerinin 0,60'ın altında kalması nedeniyle), araştırmanın en önemli kısıtı olarak kabul edilebilir. Bu kısıtlara karşılık, araştırmanın sosyal sermayeyle ilgili Türkiye'de ilçeler örnekleminde yapılan ilk araştırma olması ve elde edilen sonuçların ilçelerin ekonomik gelişmişlik düzeyleriyle ilişkisinin tespit edilmiş olması, bu anlamda izleyen araştırmalara yol göstermesi ve alana katkı sağlamasının beklenmesi açısından önem taşımaktadır.

Araştırma bulgularından hareketle genel bir değerlendirme yapıldığında, TR52 Düzey 2 bölgesinde bulunan Konya ve Karaman'a bağlı 37 ilçe arasında en yüksek sosyal sermaye düzeyine Selçuklu ilçesinin sahip olduğu görülmektedir. Aslında bu, beklenen bir sonuçtur. Çünkü 2012 yılı verileri esas alınarak bölgede yapılmış olan SEGE (sosyal ve ekonomik gelişmişlik endeksi) araştırması sonuçlarında en yüksek endeks değerine Selçuklu ilçesinin sahip olduğu görülmektedir. Araştırmamızda en yüksek sosyal sermaye düzeyi açısından Selçuklu ilçesini sırasıyla Karatay, Sarıveliler ve Meram ilçeleri takip etmektedir. SEGE sonuçlarında bu sıralama Meram, Karatay ve Ereğli olarak görülmektedir. Aslında buradaki sonuçlar arasında en ilginç olanı, çok küçük bir ilçe olması ve ekonomik açıdan gelişmiş olmamasına rağmen bölgedeki 37 ilçe arasında en yüksek sosyal sermaye düzeyine sahip 3. ilçenin Sarıveliler olmasıdır. Sarıveliler ilçesi, SEGE sonuçlarına göre 25. sıradadır. $\mathrm{Bu}$ durum, araştırmanın en ilginç bulgusu olarak değerlendirilebilir. Bu durumun, her ne kadar ekonomik açıdan çok gelişmiş bir ilçe olmasa da, Sarıveliler ilçesinin kaba boşanma hızının son derece düşük olması ve net göç hızının çok yüksek olmasına bağlı olduğu düşünülmektedir. 37 ilçe arasında sosyal sermaye düzeyi en düşük ilçe Hadim iken, bunu sırasıyla Derebucak, Halkapınar ve Doğanhisar takip etmiştir. 
TR52 Düzey 2 Bölgesi’nde (Konya ve Karaman’da) yer alan 37 ilçenin sosyal sermaye açısından gruplandırılması sonuçları incelendiğinde Selçuklu, Karatay, Sarıveliler ve Meram ilçelerinin en yüksek düzeyde sosyal sermayeye sahip ilçeler grubunu oluşturduğunu görmekteyiz. 14 ilçe (Yalıhüyük, Kulu, Beyşehir, Karaman Merkez, Taşkent, Ereğli, Altınekin, Çumra, Karapınar, Sarayönü, Ermenek, Akşehir, Seydişehir, Kazımkarabekir) sosyal sermayesi yüksek ilçeler grubuna alınmıştır. 10 ilçe (Kadınhanı, Ilgın, Çeltik, Ayrancı, Tuzlukçu, Güneysınır, Emirgazi, Cihanbeyli, Derbent, Ahırlı) sosyal sermayesi orta düzeydeki ilçeler grubunda iken, 7 ilçe (Akören, Bozkır, Hüyük, Yunak, Başyayla, Doğanhisar, Halkapınar) sosyal sermayesi düşük ve 2 ilçe (Derebucak, Hadim) sosyal sermayesi en düşük grubuna dâhil edilmiştir.

TR52 Düzey 2 bölgesi için elde edilen endeks değerlerinden yola çıkarak hazırlanan sosyal sermaye haritası incelendiğinde, genel olarak yüksek sosyal sermaye düzeyi açısından bölge merkezinde bir yoğunlaşmanın olduğu göze çarpmaktadır. Her ne kadar dağılım biraz karışık görünse de, genel bir ayrım yapılmak istenirse, bölgenin merkezine doğru yaklaştıkça sosyal sermaye düzeyinin yükseldiği söylenebilir. Avrupa ülkelerinde genellikle kuzey bölgelerinin, güney bölgelerine nazaran sosyal sermaye düzeylerinin yüksek olması profilinin, ya da Türkiye'de batı bölgelerinin doğu bölgelerine nazaran daha yüksek sosyal sermaye düzeyine sahip olması profilinin araştırmamızda aynı yönde olmadığı görülmektedir.

Araştırma kapsamında TR52 Düzey 2 bölgesinde yer alan ilçelerin sosyal sermaye değerleri ile SEGE değerleri arasında anlamlı ilişki olup olmadığına yönelik oluşturulan hipotezin testinde Pearson İlişki Analizi kullanılmıştır. Analiz sonucunda korelasyon katsayısı 0,609 olarak bulunmuş ve söz konusu değişkenler arasında \%1 önem düzeyinde istatistiksel olarak anlamlı ilişki tespit edilmiştir. Buna göre H1 "İlçelerin sosyal sermaye değerleriyle SEGE değerleri arasında anlamlı ilişki vardır” hipotezi kabul edilmiştir. Bu sonuçlara göre Konya ve Karaman'ın ilçeleri için sosyal sermaye düzeyleri ile SEGE değerleri arasında paralellik olduğu görülmektedir. Bu iki değişken arasında bir neden sonuç ilişkisi olmamakla birlikte, sosyal sermaye endeks değerleriyle SEGE değerlerinin birlikte artıp azaldığı yorumu yapılabilir. Bu da literatürde genel kabul görmüş olan sosyal sermaye düzeyi ile ekonomik gelişmişlik arasındaki ilişkiyi anlamlı bulan araştırmalara (Koç ve Ata, 2012; Şavkar, 2011; Boulila, 2008; Woodhouse, 2006; Sabatini, 2005; Annen, 2003; Zak ve Knack, 2001; Temple ve Johnson, 1998; Knack ve Keefer, 1996; Helliwell ve Putnam, 1995; Putnam, 1993; Mankiw vd., 1992) katkı niteliğindedir.

Konya ve Karaman'ın ilçeleri düzeyinde sosyal sermaye analizinin yapılması, bölgeye yönelik sonraki yıllara ilişkin stratejilerin tespitinde ve kaynakların etkin kullanımına yapacağı katkı anlamında son derece büyük öneme sahiptir. Böyle bir çalışma, bölgedeki yerel idarelerin ve yön verici olan merkezi idarenin stratejik kararlarına, planlama 
çalışmalarına ve bölgesel kaynakların kullanılacağı alanların tespitine yönelik önemli açılımlar sağlayabilecektir. Böylece bölgesel kaynakların etkin kullanımına dolaylı katkı sağlanmış olabilir.

Araştırma bulguları ve yazın taramasından elde edilen bilgiler 1şı̆̆ında, sosyal sermaye konusunda ilçeler düzeyinde yapılacak araştırmaların karşılaştırmaları mümkün kılacak şekilde artırılması gerekmektedir. Bu bakış açısı ile araştırmanın ulaştığı sonuçlar, ilçelerin ekonomik gelişmişlik düzeylerinin artırılabilmesi için sosyal sermaye düzeylerinin artırılması gerektiğine vurgu yapmaktadır. Araştırma bulgularından hareketle, uygulamanın farklı ilçeler örnekleminde tekrar edilmesi, sosyal sermaye endeks hesaplamalarının farklı yıllardaki verilerin temin edilmesi suretiyle karşılaştırmaları mümkün kılabilecek şekilde yapılması ve analizlerde kullanılan gösterge sayılarının artırılması önerilmektedir.

\section{Kaynakça}

Annen, K. (2003), “Social Capital, Inclusive Networks, and Economic Performance”, Journal of Economic Behaviour and Organization, Vol. 50, No. 4, 449-463.

Bartlett, M.S. (1950), "Tests of Significance in Factor Analysis”, British Journal of Mathematical and Statistical Psychology, Vol. 3, No. 2, 77-85.

Blassio, G. de \& G. Nuzzo (2009), "Historical Traditions of Civicness and Local Economic Development", Journal of Regional Science, Vol. 50, No. 4, 833-857.

Boulila, G. \& L. Bousrih \& M. Trabelsi (2008), "Social Capital and Economic Growth: Empirical Investigations on the Transmission Channels", International Economic Journal, Vol. 22, No. 3, 399-417.

Briggs, Xavier de Souza (1997), "Social Capital and the Cities: Advice to Change Agents", The National Civic Review, Vol. 86, No. 2, 111-117.

Bullen, P. \& J. Onyx (1998), Measuring Social Capital in Five Communities in NSW, Centre for Australian Community Organisations and Management, Working Paper Series No. 41, Australia.

Carpenter, J.P. \& A.G. Daniere \& L.M. Takahashi (2004), "Social Capital and Trust in South-east Asian Cities", Urban Studies, Vol. 41, No. 4, 853-874.

Çalışkan, D. (2010), "Yenilikçi Oluşumlarda Sosyal Sermayenin Rolü ve Burdur İli Üzerine Bir Araştırma”, Yüksek Lisans Tezi, Süleyman Demirel Üniversitesi Sosyal Bilimler Enstitüsü, Isparta.

Field, A. (2000), Discovering Statistics Using SPSS for Windows, Sage Publications, New Delhi.

Filiztekin, A. (2009), “Türkiye İçin Bir Rekabet Endeksi, EDAM ve Deloitte Türkiye Ortak Yayını”, <edam.org.tr/document/trkiye\%20icin\%20bir\%20rekabet\%20endeksi.pdf〉, 15.09.2014.

Fukuyama, F. (2001), "Social Capital, Civil Society, and Development”, Third World Quarterly, Vol. 22, No. 1, 7-20. 
Glaeser, E.L. \& D. Laibson \& B. Sacerdote (2002), “The Economic Approach to Social Capital”, Economic Journal, Vol. 112, No. 483, 437-458.

Grootaert, C. (1998), "Social Capital: The Missing Link?", The World Bank Social Development Department, Social Capital Working Paper Series, Social Capital Initiative Working Paper No. 3.

Helliwell, J. \& R.D. Putnam (1995), "Economic Growth and Social Capital in Italy", Eastern Economic Journal, Vol. 21, No. 3, 295-307.

Kara, M. (2008), "Bölgesel Rekabet Edebilirlik Kavramı ve Bölgesel Kalkınma Politikalarına Yansiması", DPT Uzmanlık Tezi, DPT Yayın No. 2774, Ankara.

Koç, A. \& A.Y. Ata (2012), "Sosyal Sermaye ve Ekonomik Büyüme İlişkisi: AB Ülkeleri ve Türkiye Üzerine Ampirik Bir İnceleme”, Süleyman Demirel Üniversitesi İktisadi ve İdari Bilimler Fakültesi Dergisi, Cilt 17, Say1 1, 199-218.

Knack, S. \& P. Keefer (1996), “Does Social Capital Have an Economic Payoff?”, Quarterly Journal of Economics, Vol. 112, No. 4, 1251-1288.

Mankiw, N.G. \& D. Romer \& D.N. Weil (1992), “A Contribution to the Empirics of Economic Growth", The Quarterly Journal of Economics, Vol. 107, No. 2, 407-437.

Mayer, M. (2003), "The Onward Sweep of Social Capital: Causes and Consequences for Understanding Cities, Communities and Urban Movements", International Journal of Urban and Regional Research, Vol. 27, No. 1, 108-130.

OECD (2001), The Well-Being of Nations: The Role of Human and Social Capital, OECD Press.

Özdamar, K. (2004), Paket Programlar ile İstatistiksel Veri Analizi (Çok Değişkenli Analizler), Kaan Kitabevi, Eskişehir.

Paldam, M. \& G.T. Svendsen (2000), "Missing Social Capital and the Transition in Eastern Europe", University of Aarhus, Aarhus School of Business, Department of Economics, Working Papers 00-5, <http://research.asb.dk/ws/fbspretrieve/250/00-5_gts.pdf>, 28.06.2014.

Perez, F. \& Guevara, J.F. de \& L. Serrano \& V. Montesinos (2006), Measurement of Social Capital and Growth: an Economic Methodology, Documentos de Trabajo - Fundación BBVA No. 4, MPRA Munich Personal RePEc Archive, Paper No. 16006, <http://mpra.ub.unimuenchen.de/16006/>, 16.06.2014

Putnam, R.D. (1995a), “Tuning in, Tuning out: The Strange Disappearance of Social Capital in America", Political Sciences and Politics, Vol. 28, No. 4, 664-683.

Putnam, R.D. (1995b), “Bowling Alone: America's Declining Social Capital”, Journal of Democracy, Vol. 6, No. 1, 65-78.

Putnam, R.D. (1993), "The Prosperous Community: Social Capital and Public Life", The American Prospect, Vol. 4, No. 13, 35-42.

Putnam, R.D. \& R. Leonardi \& R.Y. Nanetti \& F. Pavoncello (1993), "Explaining Institutional Success: The Case of the Italian Regional Government", American Political Science Review, Vol. 77, March, 55-74.

Rupasingha, A. \& S.J. Goetz \& D. Freshwater (2006), "The Production of Social Capital in US Counties", The Journal of Socio-Economics, Vol. 35, 83-101. 
Sabatini, F. (2005), The Role of Social Capital in Economic Development: Investigating the Causal Nexus through Structural Equations Models, EconWPA Development and Comp Systems, No. 0512010.

Sangün, L. (2007), "Temel Bileşenler Analizi, Ayırma Analizi, Kümeleme Analizleri ve Ekolojik Verilere Uygulanması Üzerine Bir Araştırma”, Doktora Tezi, Çukurova Üniversitesi Fen Bilimleri Enstitüsü, Adana.

Schiff, M. (1992), 'Social Capital, Labor Mobility, and Welfare: the Impact of Uniting States”, Rationality and Society, Vol. 4, No. 2, 157-175.

Şavkar, E. (2011), “Sosyal Sermayenin Unsurları ve Ekonomik Kalkınmayla İlişkisi”, Yüksek Lisans Tezi, Afyon Kocatepe Üniversitesi Sosyal Bilimler Enstitüsü, Afyon.

Temple, J. \& P.A. Johnson (1998), "Social Capability and Economic Growth”, The Quarterly Journal of Economics, Vol. 113, No. 3, 965-990.

Tüysüz, N. (2011), "Sosyal Sermayenin Ekonomik Gelişme Açısından Önemi ve Sosyal Sermaye Endeksinin Hesaplanması", T.C. Kalkınma Bakanlığı Planlama Uzmanlığı Tezi, T.C. Kalkınma Bakanlığı Yayınları No. 2827, Ankara.

Uğuz, H.E. \& E. Örselli \& Ş. Tüylüoğlu \& F. Mazı \& E.B. Sipahi (2011a), “Türkiye'nin Sosyal Sermaye Stoğunu ve Toplumun Sosyal Sermaye Profilini Belirlemeye Yönelik Bir Alan Araştırması", TÜBITTAK 1001 Araştırma Projesi, Proje No. 110K133.

Uğuz, H.E. \& E. Örselli \& E.B. Sipahi (2011b), “Sosyal Sermayenin Ölçümü: Türkiye Deneyimi”, Akademik Incelemeler Dergisi, Cilt 6, Say1 1, 8-40.

Woodhouse, A. (2006), "Social Capital and Economic Development in Regional Australia: A Case Study", Journal of Rural Studies, Vol. 22, No. 1, 83-94.

Zak, P.J. \& S. Knack (2001), “Trust and Growth”, The Economic Journal, Vol. 111, No. 470, 295321. 